\title{
EVIDENCE FROM MEASURING COMMUNITY FLOOD RESILIENCE IN ASIA
}

Finn Laurien and Adriana Keating

NO. 595

October 2019
ADB ECONOMICS WORKING PAPER SERIES 


\section{ADB Economics Working Paper Series}

\section{Evidence from Measuring Community Flood Resilience in Asia}

Finn Laurien and Adriana Keating

No. 595 | October 2019
Finn Laurien (laurien@iiasa.ac.at) is a research assistant and Adriana Keating (keatinga@iiasa.ac.at) is a research scholar at the International Institute for Applied Systems Analysis.

This paper was prepared as background material for the Asian Development Outlook 2019 theme chapter on "Strengthening Disaster Resilience." 
(C) 2019 Asian Development Bank 6 ADB Avenue, Mandaluyong City, 1550 Metro Manila, Philippines

Tel +632632 4444; Fax +6326362444

www.adb.org

Some rights reserved. Published in 2019.

ISSN 2313-6537 (print), 2313-6545 (electronic)

Publication Stock No. WPS190484-2

DOI: http://dx.doi.org/10.22617/WPS190484-2

The views expressed in this publication are those of the authors and do not necessarily reflect the views and policies of the Asian Development Bank (ADB) or its Board of Governors or the governments they represent.

ADB does not guarantee the accuracy of the data included in this publication and accepts no responsibility for any consequence of their use. The mention of specific companies or products of manufacturers does not imply that they are endorsed or recommended by ADB in preference to others of a similar nature that are not mentioned.

By making any designation of or reference to a particular territory or geographic area, or by using the term "country" in this document, $A D B$ does not intend to make any judgments as to the legal or other status of any territory or area.

This work is available under the Creative Commons Attribution 3.0 IGO license (CC BY 3.0 IGO)

https://creativecommons.org/licenses/by/3.o/igo/. By using the content of this publication, you agree to be bound by the terms of this license. For attribution, translations, adaptations, and permissions, please read the provisions and terms of use at https://www.adb.org/terms-use\#openaccess.

This CC license does not apply to non-ADB copyright materials in this publication. If the material is attributed to another source, please contact the copyright owner or publisher of that source for permission to reproduce it. $\mathrm{ADB}$ cannot be held liable for any claims that arise as a result of your use of the material.

Please contact pubsmarketing@adb.org if you have questions or comments with respect to content, or if you wish to obtain copyright permission for your intended use that does not fall within these terms, or for permission to use the ADB logo.

Corrigenda to ADB publications may be found at http://www.adb.org/publications/corrigenda.

Notes:

In this publication, “\$” refers to United States dollars.

ADB recognizes "Vietnam" as Viet Nam.

The ADB Economics Working Paper Series presents data, information, and/or findings from ongoing research and studies to encourage exchange of ideas and to elicit comment and feedback about development issues in Asia and the Pacific. Since papers in this series are intended for quick and easy dissemination, the content may or may not be fully edited and may later be modified for final publication. 


\section{CONTENTS}

TABLES AND FIGURES

$\begin{array}{ll}\text { I. INTRODUCTION } & 1\end{array}$

II. BACKGROUND: COMMUNITY DISASTER RESILIENCE CONCEPTS AND METRICS 3

A. What is Community Disaster Resilience? 3

B. Measuring Community Disaster Resilience 4

III. METHODS: MEASURING DISASTER RESILIENCE

A. Data Collection $\quad 6$

B. Statistical Analysis Methods 10

$\begin{array}{ll}\text { IV. RESULTS } & 10\end{array}$

A. Differences by Settlement Type 11

B. Analyzing Strengths and Weaknesses $\quad 13$

$\begin{array}{ll}\text { V. CASE STUDIES } & 18\end{array}$

A. Urban Indonesia $\quad 18$

B. Rural Afghanistan $\quad 21$

VI. CONCLUSIONS AND RECOMMENDATIONS 22

$\begin{array}{ll}\text { APPENDIXES } & 25\end{array}$

$\begin{array}{ll}\text { REFERENCES } & 41\end{array}$ 


\section{TABLES AND FIGURES}

\section{TABLES}

1 Description of Most Relevant Socioeconomic Community Characteristics for 7

$2 \quad$ Number of Communities in Each Country and Total Estimated Population for 9

3 Financial Recovery Time from Last Severe Flood 11

$4 \quad$ Settlement Type Results for Socioeconomic Characteristics 12

5 Analysis of Flood Resilience Scores across Themes and Steps of the Disaster 16

A1 Sources of Resilience $\quad 25$

A2.1 Tests of Normality with Kolmogorov-Smirnov and Shapiro-Wilk 29

A2.2 Test of Homogeneity of Variances 30

A2.3 Hypothesis Test Summary of Independent Samples, Kruskal-Wallis Test 30

A2.4 Descriptive Statistics of Theme Lens for Kruskal-Wallis Test 31

A2.5 Assets and Livelihoods across Settlement Types with Independent Samples, 32 Kruskal-Wallis Test Summary

A2.6 Post-Hoc Test for Assets and Livelihoods Pairwise Comparisons of Settlement 33 Types with Independent Samples, Kruskal-Wallis Test

A2.7 Education across Settlement Types with Independent Samples, 33 Kruskal-Wallis Test Summary

A2.8 Post-Hoc Test for Education Pairwise Comparisons of Settlement 33

Types with Independent Samples, Kruskal-Wallis Test

A2.9 Energy across Settlement Types with Independent Samples, Kruskal-Wallis Test Summary 33

A2.10 Post-Hoc Test for Energy Pairwise Comparisons of Settlement Types with Independent 34 Samples, Kruskal-Wallis Test

A2.11 Food across Settlement Types with Independent Samples, Kruskal-Wallis Test Summary 34

A2.12 Post-Hoc Test for Food Pairwise Comparisons of Settlement Types with Independent 34 Samples, Kruskal-Wallis Test

A2.13 Governance across Settlement Types with Independent Samples, Kruskal-Wallis 34 Test Summary

A2.14 Health across Settlement Types with Independent Samples, Kruskal-Wallis 35 Test Summary

A2.15 Environment across Settlement Types with Independent Samples, Kruskal-Wallis 35 Test Summary

A2.16 Transportation and Communication across Settlement Types with Independent Samples, 35 Kruskal-Wallis Test Summary

A2.17 Post-Hoc Test for Transportation and Communication Pairwise Comparisons of 35 Settlement Types with Independent Samples, Kruskal-Wallis Test

A2.18 Waste across Settlement Types with Independent Samples, Kruskal-Wallis 36 Test Summary

A2.19 Post-Hoc Test for Waste Pairwise Comparisons of Settlement Types with Independent 36 Samples, Kruskal-Wallis Test

A2.20 Water across Settlement Types with Independent Samples, Kruskal-Wallis 36 Test Summary

A2.21 Post-Hoc Test for Water Pairwise Comparisons of Settlement Types with Independent 36 Samples, Kruskal-Wallis Test 
A3.1 Tests of Normality with Kolmogorov-Smirnov and Shapiro-Wilk 37

A3.2 Test of Homogeneity of Variances

A3.3 Hypothesis Test Summary of Independent Samples, Kruskal-Wallis Test 38

A3.4 Descriptive Statistics of Disaster Risk Management Cycle Properties for 38 Kruskal-Wallis Test

A3.5 Prospective Risk Reduction across Settlement Types with Independent Samples, 39 Kruskal-Wallis Test Summary

A3.6 Post-Hoc Test for Prospective Risk Reduction: Pairwise Comparisons of Settlement 39 Types with Independent Samples, Kruskal-Wallis Test

A3.7 Corrective Risk Reduction across Settlement Types with Independent Samples, 39 Kruskal-Wallis Test Summary

A3.8 Crisis Preparedness across Settlement Types with Independent Samples, 39 Kruskal-Wallis Test Summary

A3.9 Coping across Settlement Types with Independent Samples, Kruskal-Wallis 40 Test Summary

A3.10 Post-Hoc Test for Coping Strategies: Pairwise Comparisons of Settlement 40 Types with Independent Samples, Kruskal-Wallis Test

\section{FIGURES}

1 The Flood Resilience Measurement for Communities Data Collection Process 8

2 Distribution of Flood Resilience Scores by Settlement Types 12

3 Theme-Specific Strengths and Weaknesses Across Settlement Types 14

4 Disaster Risk Management-Specific Strengths and Weaknesses across 14

5 Distribution of Grades for 88 Sources of Resilience in Five Types of Capital, 19 Urban Indonesia (Semarang City)

6 Decision-Making Assessment in Terms of Urgency and Importance 20 for Flood Resilience Implementation Process

7 Distribution of Grades for 88 Sources of Resilience in Five Types of Capital, 21 Rural Afghanistan 


\begin{abstract}
Disaster risk and subsequent loss and damage in Asia are increasing at an alarming rate, threatening socioeconomic gains. Arresting this rapid increase in exposure requires risk-informed development and urban planning-a challenging proposition complicated by multiple economic and political incentives. To reduce these risks, action at the national and regional levels must be complemented by action at the community level. Measuring community disaster resilience can help lead to novel and systemic investments that build community resilience. Our analysis of community flood resilience data finds deficiencies and potential for substantial improvements in community flood resilience investment across the region, with different recommendations for urban, peri-urban, and rural locations. Our evidence from case studies shows that interventions prioritized by the measurementinformed process are more likely to succeed and be sustainable and have cobenefits for community development.
\end{abstract}

Keywords: assets and livelihoods, decision making, disaster, flood, measurement, resilience, waste management

JEL codes: C81, P25, Q54, Q57 


\section{INTRODUCTION}

In 2017 alone, disasters caused a reported $\$ 9.4$ billion worth of damage across the Asian region (CRED 2018); a figure that is likely a gross underestimation (Wirtz et al. 2014, Guha-Sapir and Below 2002, Ladds et al. 2017). The number of people in Asia living and working in areas exposed to disasters is increasing, in many cases at a higher rate than population growth (UNISDR 2011). The critical driving force behind this increase in the disaster-exposed population is high migration into at-risk areas, particularly flood-affected coastal zones (CRED 2015). Within Asia, where $90 \%$ of the world's floodexposed people live, floods are the most frequent type of disaster. Between 1970 and 2014, more people were affected by floods than by all other disaster types combined. The incidence of flooding in the region is growing steeply (UNESCAP 2015). When mapping the locations of the world's major floods from 1985 to 2010, Kundzewicz et al. (2014) found that many are centered in South and East Asian hubs of economic development. There is an urgent need to tackle this challenge before further socioeconomic drivers and climate change converge to create unprecedented risk of catastrophes that could undo decades of economic growth across Asia. Resilience has emerged as a concept with much potential to help address this difficult problem (Keating et al. 2016). This paper presents evidence from a recent community flood resilience measurement program in 88 communities across Asia.

Disasters pose a significant threat to Asia's socioeconomic growth, particularly by undermining business performance, long-term competitiveness, and sustainability (UNISDR 2013). Especially in rural areas, disasters can trap people in poverty, rendering them unable to benefit from or contribute to Asia's economic growth, and in some cases forcing them to migrate to cities out of economic necessity (Berhanu 2011; Carter et al. 2007; Jakobsen 2012; Heltberg, Hossain, and Reva 2012). Not only can disasters impact development and urbanization trends, but the drive for economic development is the key force behind increasing disaster risk. This is because the increased population movement and economic connectivity of development draws people to hazardous areas, especially on the outskirts of cities (Hallegatte 2011; Fernandez and Sanahuj 2012; Braun and Assheuer 2011; UNISDR 2011, 2015). For example, in Bangladesh, internal rural-to-urban migration is resulting in a population explosion in the highly flood-exposed slums of the capital Dhaka (Braun and Assheuer 2011).

The current approach to disaster risk management (DRM) could be enhanced to more effectively tackle these troubling trends. This evolution in approach is required because while the Hyogo Framework for Action (UNISDR 2005) years (2005-2015) saw significant progress in reducing disaster-related mortality (in relative terms) (UNISDR 2013), similar success was not seen in tackling the underlying drivers of increasing disaster risk (UNISDR 2015). This is for two key reasons: Firstly, it requires ex ante risk reduction, which is difficult to motivate because of skewed incentives, including biased perception of risk, cognitive biases, and budget constraints (Kunreuther, Meyer, and MichelKerjan 2013) as well as political disincentives to reduce risk (Bull-Kamanga et al. 2003). Secondly, that ex ante action must take an integrated and holistic approach-a systems-based approach-rather than an approach narrowly focused on hazard management (Keating et al. 2016).

A systems-based approach, also denoted by terms such as "integrated" or "holistic," is one that considers the complex and dynamic interconnections between disaster risk, disaster impacts, DRM, and development more generally. It considers not only physical or economic aspects, but human, social, and environmental ones, too. Taking such a systems-based approach to tackle these drivers is often outside the sphere of influence of the DRM sector as it currently exists, since it requires that disaster risk be mainstreamed into much wider decision-making on infrastructure investment, urban planning, and many other development arenas. The value of this type of approach has been recognized for some time, for example, in social risk management championed by the World Bank (2003). Social 
risk management has long recognized that tackling underlying economic vulnerability is essential for ensuring that shocks do not derail development and as such, is intrinsically interconnected with DRM. Like social risk management, a systems-based approach to DRM requires shifts in thinking.

The tools commonly used in the DRM space to inform investment decision-making-namely economic optimization methods such as cost-benefit analysis (CBA) - also fall victim to these difficulties. When assessing the application of CBA for disaster risk reduction, Mechler et al. (2014) find that these assessments rarely consider multiple disaster risk reduction interventions, and systemic interventions are "almost completely ignored" (Mechler et al. 2014, 40). CBA struggles to take full account of the costs and benefits of ex ante risk reduction because the intangible costs of disasters, such as mortality, environmental amenity, ecosystem services, and cultural heritage, are notoriously difficult to estimate monetarily (Venton and Venton 2004, MMC 2005, Mora et al. 2009, Mechler et al. 2008). Other issues include difficulties in selecting discount rates (and fundamental objections to their use at all), and the assumption that people are risk neutral. Finally, Mechler et al. (2014) contend that the lack of compensation for costs bared in practice (in violation of the Kaldor-Hicks criterion) means that distribution of costs and benefits remains a key challenge.

Slowing the rapid increase in exposure across Asia requires risk-informed development and urban planning-a challenging proposition complicated by conflicting economic and political incentives (Schipper and Pelling 2006, Bull-Kamanga et al. 2003, Wamsler and Brink 2014, Keating et al. 2016). Traction to address the proliferating disaster risk across Asia requires a shift in approach, away from the status quo to one that can shine a light on the underlying drivers of risk and motivate investment in a more systemic way. Therefore, resilience has been identified as a useful concept in the field, because it has the potential to facilitate a shift in perspective and practice toward a holistic and integrated approach that emphasizes ex ante.

In addition to a conceptual shift toward resilience, there is a parallel need to focus on addressing disaster impacts and risk management options at the community level. This is because disaster impacts are felt most viscerally at the community level and therefore, community-level actions to tackle growing disaster risk and address impacts can be highly cost-effective. Currently, the need for investments in DRM is receiving increasing attention at the national level. For example, all Asian countries are signatories to the Sendai Framework for Disaster Risk Reduction, which outlines muchneeded national-level action (UNISDR 2015). Aggregated information about disaster impacts and DRM needs at the national level is becoming more readily available, for example, in the form of databases, including in support of Hyogo and Sendai reporting frameworks. In contrast, information about community-level disaster impacts and risk management options is typically ad hoc, location specific, and qualitative. When undertaken using methods such as CBA, community DRM investment planning tends to be narrow and static. Bringing these together, we suggest that protecting Asia's socioeconomic growth requires complementing national-level action with bolstering investment to build community-level disaster resilience, informed by data from community disaster resilience measurement endeavors.

In this paper, we provide in the background section an overview of the concept of disaster resilience, and key precepts and challenges of measurement, particularly at the community level. In this overview, we highlight the need for data to inform investment in community-level disaster resilience building, by community-based organizations, such as nongovernment organizations (NGOs). In the methods section, we describe an approach to measuring community resilience to flooding, by which we have gathered the data used in our analysis. We then present and discuss the results of our analysis, highlighting key measures pertinent to community flood resilience across Asia. 
Evidence from Measuring Community Flood Resilience in Asia | 3

Finally, we present two case studies that provide an in-depth look at how measurement can mobilize investment into building community flood resilience in practice.

\section{BACKGROUND: COMMUNITY DISASTER RESILIENCE CONCEPTS AND METRICS}

\section{A. What is Community Disaster Resilience?}

The concept of "resilience" has a long history and different disciplines have provided a variety of perspectives. Throughout the 20th century, the term was adopted in the fields of engineering to design fail-safe production systems (Davoudi et al. 2012, Holling 1996, Ashley et al. 2008); psychology regarding recovery from adversity or trauma (Welsh 2014, Berkes and Ross 2013); ecological systems theory on the persistence of the bio-ecosystem following a disturbance (Holling 1973); and economics regarding the efficiency of resource allocation and input mobility during a shock, and how quickly the economy can return to efficiency after the shock (Rose 2009).

The central theme that unites the various perspectives on resilience is that of response and recovery from shocks, and thus, it seems a natural extension that the concept be applied in disasters research and practice. The use of the term resilience in relation to disasters has increased exponentially over the last decade (Meerow and Newell 2015, Gostelow et al. 2016). It initially drew on the psychology field, where the ideal of individual resilience to shocks was applied to community resilience (Berkes and Ross 2013). This was intuitive for emergency responders and the NGO and humanitarian sector, who are on the front lines with individuals and communities after an event. The concept was soon broadened, supported by academic research, to incorporate the ecological perspective, espoused by Holling $(1973,1996,2001)$, which drew on fundamental ideas about linked social-ecological systems. This complemented thinking on the human dimension of natural disasters. The concept has been further extended to the national and regional levels as resilience has entered the global arena. Theory and experience in sustainable community development have also contributed to the debate to identify the attributes of communities that enhance their resilience, such as social networks, communications, social capital, leadership, and culture (Berkes and Ross 2013).

In the disasters field, theorists and practitioners have identified resilience as a concept that may be able to interrupt some of the entrenched issues in contemporary DRM practice (Béné et al. 2012, Davoudi et al. 2012, Mitchell and Harris 2012, Frankenberger et al. 2013, Mercy Corps 2013, SudmeierRieux et al. 2015, Pasteur and McQuistan 2016). In particular, the systems-analysis roots of the concept have been heralded as having the potential to link the development and DRM fields and thereby motivate ex ante, holistic, and integrated action to tackle the underlying drivers of increasing risk.

Resilience is a concept with its roots in systems analysis (Adger et al. 2005, Folke 2006, Barrett et al. 2014), and policy makers and practitioners guided by it have the potential to engender an integrated and holistic approach to disaster policy and practice. This contrasts with the status quo, where action to prepare for disasters (crisis preparedness), facilitate good recovery (coping), and critically reduce disaster risk (corrective risk reduction) or prevent its buildup (prospective risk reduction) typically ignores the complex human, social, and environmental factors that are critical for long-term success. For example, embankments are an important intervention in the flood risk management space, yet the impacts of embankments on riverine ecosystems are often not considered. This can result in suboptimal and unsustainable interventions, and negative environmental impacts that may in fact increase disaster risk in the long term (Sendzimir et al. 2008, Heine and Pinter 2012). 
A number of scholars have reviewed available definitions of disaster resilience, and the elements described above are identified in these reviews. While the definition of disaster resilience is by no means agreed, and differences in conceptualization remain a contentious issue in the field, several common elements are evident. Definitions of disaster resilience focus primarily on the capacity (of the system in question - be it a household, community, city, or nation) to persist in the face of, and recover from, disasters. Some definitions imply recovery to the previous state, while others demand that the event does not impede existing upward trends in development generally or economic growth specifically. The capacity and inclination to undertake ex ante action is a further core feature in many definitions (Keating et al. 2016). The Asian Development Bank (ADB) defines disaster resilience as:

The ability of countries, communities, businesses, and individual households to resist, absorb, recover from, and reorganize in response to natural hazard events, without jeopardizing their sustained socioeconomic advancement and development (ADB 2013).

Delving into this definition in detail, we can observe two important elements for our discussion. Firstly, we note that while the phrase "in response to" may imply a focus on the emergency and postdisaster phases, the focus on the "ability" to respond shows the focus on ex ante action. This is because to build the ability to respond, actions must be taken in the predisaster phase. Secondly, the key point to note is the phrase "without jeopardizing their sustained socioeconomic advancement and development." We surmise that this phrase has been included because of a recognition that disasters may in fact derail development. Furthermore, this phrase also brings with it an acknowledgment that actions to manage disaster risk themselves can also impede development. Phrased another way, we can infer that ADB (ADB 2013) views disaster resilience as the capacity of a system to withstand disasters and undertake DRM in a way that does not derail positive development trends. ${ }^{1}$

As discussed above, it is at the community level that disaster impacts are most significant to peoples' lives. In general, there exists a need and a potential to address the underlying drivers of disaster risk and build resilience in communities. From the definitions outlined in the literature and by multilateral organizations such as $\mathrm{ADB}$, we have a picture of what community disaster resilience looks like in action. We also know from our review that a significant part of the appeal of disaster resilience comes from its systems-oriented, holistic, and integrated approach that prioritizes ex ante action. Yet none of this knowledge tells us what properties enable a community to build its capacity to cope with disasters and undertake DRM without derailing its development trajectory.

\section{B. Measuring Community Disaster Resilience}

Across the world and in Asia, there is little data about community disaster resilience attributes, the impacts of disasters at the community level, or communities' disaster-related policy and practice needs. Quantified information is critical for several reasons: (i) it allows for tracking community progress over time in a standardized way and prioritizing measures most needed by the community; (ii) it generates evidence for what characteristics contribute most to community disaster resilience "before" an event strikes; and (iii) it provides the evidence to mobilize investment in building community disaster resilience, especially ex ante action.

Note that there is substantial conceptual overlap between the ADB definition of disaster resilience and the one underpinning the measurement framework presented below (Keating et al. 2016, 2017). 
Our review of the literature, as with other reviews of disaster resilience measurement frameworks (Schipper and Langston 2015; Winderl 2014; Ostadtaghizadeh et al. 2015; Oddsdóttir, Lucas, and Combaz 2013; Asadzadeh et al. 2017; Rus, Kilar, and Koren 2018), identifies a number of key precepts and challenges associated with measuring disaster resilience. We note that the extremely scale-, place-, and system-specific nature of shocks creates difficulties when attempting to generalize a set of key factors that enhance resilience (Tol and Yohe 2007, Vincent 2007). Relatedly, issues associated with measurement vary depending on the scale of the measurement. To reduce this complexity somewhat, we present issues pertinent to the community scale, since this is our focus.

Carpenter et al. (2001) argued that when constructing and using resilience indicators or measurement frameworks, there is a need to establish the geographical and temporal scale of analysis (resilience of what?), the hazard or shock in question (resilience to what?), and the intended audience (indicators for whom?). Here we focus on the resilience of communities to disasters, while noting community disaster resilience indicators can be used by different groups for different purposes. Indicators need to be specific enough to be useful, but general enough to allow for wide applicability. Schipper and Langston (2015) point out that it is possible for a system, such as a community, to have high resilience in relation to one hazard but low resilience in relation to another.

While the appeal of resilience is that it engenders an integrated and holistic approach, this translates into a significant measurement challenge. Firstly, resilience is a latent property of the community that is not revealed until after it is tested by a disaster (Engle 2011). Yet it is before the disaster strikes that community members and other stakeholders need to understand the community's disaster resilience so that investments may be made to enhance it. Secondly, this latent characteristic consists of multiple complex and interconnected elements that are often qualitative in nature. Thirdly, as a number of authors have pointed out (e.g., Berkes and Ross 2013, Welsh 2014), resilience and in particular, resilience measurement, is a normative approach. Many fields have grappled with the challenge of normative measurement of latent and qualitative characteristics, including the international development sector, offering valuable input for the disasters field. In relation to resilience measurement in particular, Maxwell et al. (2015) find that mixed method approaches implemented within sound processes can indeed generate reliable data on the latent and qualitative features of disaster resilience. Measurement frameworks are normative by nature. Because of this, framework designers and users must be cognizant of the elements included and excluded.

Since this paper focuses on the community level, the question of how to define a community is important. The concept of "community" is contested and has been critiqued in regard to its application in the development sector. It is essential to note that communities do not have clearly defined boundaries; they are not homogenous entities, nor are they static over time. Furthermore, community-level resilience is predicated on actions and capacities at the subcommunity scale (i.e., households), and the supercommunity scale (i.e., regional governments) (Béné et al. 2012, Frankenberger et al. 2014).

\section{METHODS: MEASURING DISASTER RESILIENCE}

In response to the need to measure community disaster resilience, discussed above, several initiatives have arisen to measure community disaster resilience, for example, the 100 Resilient Cities network, Resilience in East Asian Landscape initiative, Guidance for Resilience in the Anthropocene: Investments for Development program or the Building Resilience and Adaptation to Climate Extremes and Disasters project. 


\section{A. Data Collection}

The Zurich Flood Resilience Alliance developed a framework and associated tool called Flood Resilience Measurement for Communities (FRMC). Below we provide a brief description of the approach. For further details, see Keating et al. (2017). This approach is specifically designed to measure community-level resilience to flooding. The users of the FRMC tool are groups such as NGOs working in flood-prone communities who wish to inform their decisions regarding investments into community flood resilience.

The FRMC framework was developed by a collaboration between researchers, NGOs, and insurance company risk engineers. Building from the insight described above, that disaster resilience is a multidimensional capacity (Constas, Frankenberger, and Hoddinott 2014), the FRMC framework was designed to generate a holistic and integrated picture of community flood resilience capacity. By exploring flood resilience in this way, the FRMC framework explicitly draws out the links between flood resilience and development. The FRMC framework builds on a multiple capitals approach that characterizes communities by complementary forms of capital that sustain and can help to improve inhabitants' well-being. While it is by nature a normative approach, this framework attempts to center development and vulnerability theory, hoping to avoid reinforcing existing power dynamics (for these critiques, see Berkes and Ross 2013). The framework measures a property (disaster resilience) via a set of indicators, and as such has similarities to both risk assessment and vulnerability assessment frameworks. It should be noted that the framework does not measure flood risk per se, as it focuses on the community's capacities to manage their risk.

The framework comprises a set of 88 discrete indicators, called "sources of resilience" ("sources" from this point forward), that together represent a community's disaster resilience. The sources are measured in normal (nonflood) times to create a baseline ("benchmark") to compare against later, repeated measures (or "endline"). All 88 sources focus on the communities' capacity to manage their disaster risk and development over time in mutually reinforcing ways -in other words, their disaster resilience capacity. While most of the sources are focused specifically on floods, approximately $20 \%$ measure community capacity in a more general development sense. In addition to the sources, several socioeconomic variables are collected for each community.

Each source is graded from D (significantly below good standard, potential for imminent loss) to A (best practice for managing the risk). Grading is done by trained assessors, who compare data collected in the field to specific source and grade definitions. Data collection questions and grade definitions were designed such that they are universally applicable and reduce subjectivity in the assessment as much as possible. This approach was based on the extensive experience of risk engineering practice from Zurich Insurance, which works with Technical Risk Grading Standards. Technical Risk Grading Standards are technical documents that establish a standardized view of a characteristic, property, or aspect, against which trained assessors compare data gathered from site visits.

Data to inform grading is collected via mixed methods data collection including household surveys, community group discussions, focus group discussions, key informant interviews, and existing "secondary source" data. It is important to note that data collection questions were designed to avoid, as much as is feasible, privileging some types of knowledge over others. Specifically, traditional knowledge is just as valid as scientific knowledge. Socioeconomic variables collected at baseline are not graded, and data is collected by users from communities themselves or existing official or unofficial data sources. The variables relevant to our analysis are detailed in Table 1. 


\section{Table 1: Description of Most Relevant Socioeconomic Community Characteristics for Baseline Assessments}

\begin{tabular}{|c|c|}
\hline Socioeconomics Community Variables & Variable Description \\
\hline Settlement type & $\begin{array}{l}\text { Defined as rural, peri-urban, or urban. These categories are } \\
\text { defined by the population density and the community } \\
\text { functionality. }{ }^{\text {. }}\end{array}$ \\
\hline Poverty rate & $\begin{array}{l}\text { Defined as the proportion of people living below the national } \\
\text { poverty line }\end{array}$ \\
\hline Education rate & $\begin{array}{l}\text { Percentage of people who have completed high school } \\
\text { education }\end{array}$ \\
\hline Female-headed households & $\begin{array}{l}\text { Percentage of households that do not have an adult male } \\
\text { living with them regularly }\end{array}$ \\
\hline Historical flood risk & $\begin{array}{l}\text { Number and severity of flood events in the last } 10 \text { years, } \\
\text { defined as normal, significant, exceptional, or catastrophic }\end{array}$ \\
\hline Minority rate & $\begin{array}{l}\text { Percentage of the community who are identified as an } \\
\text { ethnic, religious, or otherwise identified minority within the } \\
\text { country }\end{array}$ \\
\hline \multicolumn{2}{|c|}{$\begin{array}{l}\text { a For rural communities, the population density is a sufficient control factor to distinguish between peri-urban and urban } \\
\text { communities. However, peri-urban and urban are usually characterized by different functionalities. For example, communities with a } \\
\text { regionally important functionality (such as regional water supply services or government buildings) are more likely to be defined as } \\
\text { urban communities. } \\
\text { b Users were instructed to assign a label to past floods according to the following definition based on the return period of the flood } \\
\text { hazard: normal, 1-2-year event; significant, 2-10-year event; exceptional, 10-100-year event; catastrophic, 100+-year event. } \\
\text { Source: Authors' own. }\end{array}$} \\
\hline
\end{tabular}

Figure 1 shows the process for using the FRMC tool. Field staff collect data using the mobile application, and this data is automatically uploaded to the web platform. From there, trained assessors conduct grading. Results are then displayed for interpretation by users.

To facilitate the interpretation of results, each source is tagged according to several classifications (lenses). Below, we list the elements (parts of the DRM cycle, pertinent themes or development areas, and types of capital) relevant to our analysis.

In the DRM cycle, we consider:

- Prospective risk reduction. These are activities that address and seek to avoid the development of new or increased disaster risks.

- Corrective risk reduction. These are activities that address and seek to correct or reduce disaster risks that are already present.

- Crisis preparedness. These are actions carried out before an event to build capacities needed to effectively manage the flood emergency situation and achieve orderly transitions from response to recovery and reconstruction.

- Coping. It is the ability of a community to utilize available skills and resources to manage the adverse conditions brought on by the flood. 
Figure 1: The Flood Resilience Measurement for Communities Data Collection Process

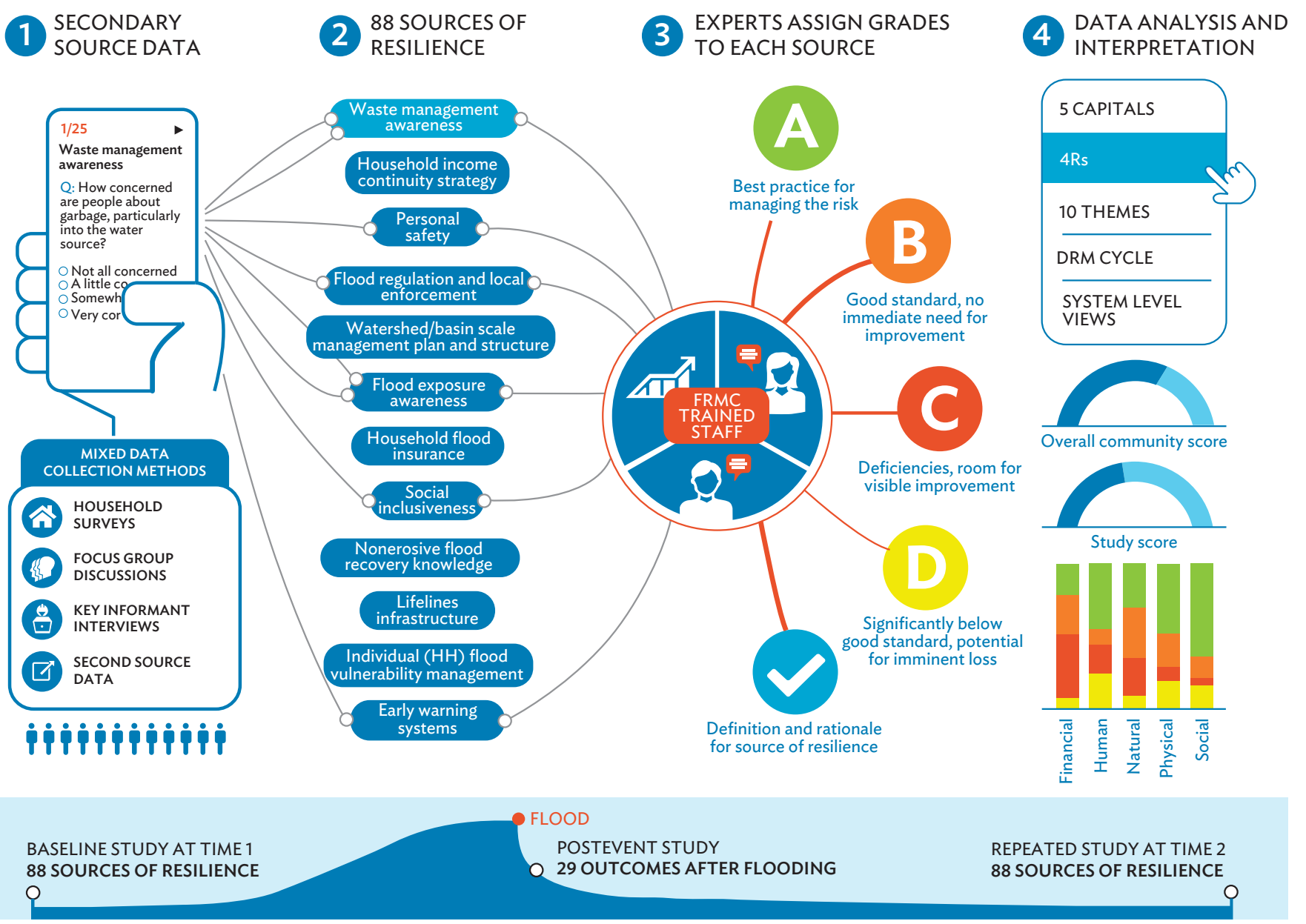

DRM = disaster risk management, $F R M C=$ Flood Resilience Measurement for Communities, $\mathrm{HH}=$ household

Notes: 4Rs refer to rapidity, robustness, redundancy, and resourcefulness; 5 capitals refer to human, social physical, financial, and natural; 10 themes include assets and livelihoods, education, energy, food, governance, life and health, natural environment, transport and communication, waste management, and water.

Source: Authors' own.

Regarding themes (i.e., development sectors) we examine life and health, education, assets and livelihoods, food, transport and communication, water, waste management, energy, governance, and natural environment.

Our research also investigates the following types of resources or "capitals":

- Human. This refers to the education, skills, and health of household members.

- Social. These are the reciprocal claims on others by virtue of social relationships and networks, the close social bonds that aid cooperative action, and the social bridging and linking, via which ideas and resources are accessed.

- Physical. These are capital items produced by economic activity from other types of capital that can include infrastructure, equipment, and improvements in genetic resources, for example, crops and livestock. 
- Financial. This refers to the level, variability, and diversity of income sources, and access to other financial resources (credit, savings, cattle) that together contribute to wealth.

- Natural. This refers to the natural resource base, for example, productivity of land, and actions to sustain productivity, as well as the water and biological resources from which livelihoods are derived.

In Asia, the FRMC tool has been applied in five countries (Afghanistan, Bangladesh, Indonesia, Nepal, and Timor-Leste) by five NGOs in seven separate country programs. Baseline studies were implemented in 88 communities during 2016-2017. The definition of "community" used was driven by the practical considerations of the NGOs using the FRMC tool, who concluded that both geographical and administrative boundaries are important depending on context, and that, overall, a community largely defines itself (Keating et al. 2017).

Communities were selected by NGO users based on socioeconomic indicators such as poverty and vulnerability, as well as flood risk based on reported flood history. Poor or otherwise vulnerable communities perceived to be at high risk of flooding were prioritized. The location of the community in the broader river basin was also considered, as well as the regional representativeness of the community. Finally, the geographical and institutional accessibility of the communities played a role in selection. It is important to note that the community selection process was not random but predicated on the user NGO's access to the community. In this way, the dataset is not a random representative sample for all of communities in the five countries. Instead, the communities are a representative picture of other communities in the same region that have a demand for resilience-building measures, due to high vulnerability to flood risks, including stemming from socioeconomic vulnerability.

In total, more than 4,000 households were directly involved, and a total of 220,000 were indirectly reached by the FRMC tool and subsequent interventions (Zurich 2018) (Table 2).

Overall, the dataset includes 40 rural communities with an average population of 1,000 people; 24 peri-urban communities with an average population of more than 8,000 people; and 24 urban communities with an average of 4,000 people. The higher number of people living in peri-urban communities can be explained by the fact that most of these communities are located in densely populated Indonesia and Bangladesh.

Table 2: Number of Communities in Each Country and Total Estimated Population for All Communities

\begin{tabular}{lcc}
\hline Country & Number of Communities & $\begin{array}{c}\text { Total Population (Estimate) } \\
\text { (thousands) }\end{array}$ \\
\hline Afghanistan & 12 & 13 \\
Bangladesh & 9 & 39 \\
Indonesia & 40 & 150 \\
Nepal & 21 & 19 \\
Timor-Leste & 6 & 4 \\
\hline Total & 88 & 220 \\
\hline
\end{tabular}

Source: Authors' own. Data reported by local nongovernment organizations. 
Our dataset includes the raw data (information collected via household surveys, community and focus group discussions, key informant interviews, and from secondary sources) and the grades assigned to the 88 sources (indicators). In this analysis, we utilize the 7,744 grades ( 88 communities by 88 sources and/or indicators), as well as raw data from the household surveys (number of households is equal to 4,332 ).

\section{B. Statistical Analysis Methods}

Empirical evidence for community flood resilience is difficult to find, and making the correct interpretation is even more difficult. When findings are made beyond community boundaries, most data analyses fail to reach clear conclusions. In this sense, we know our conclusions will never provide a complete picture of reality; rather we aim to highlight commonalities between communities and make suggestions for shared learnings across communities.

In this section, we describe the statistical methods that were applied to examine the FRMC dataset. For the analysis in the next section, we assess the ordinal scaled sources of resilience by translating the $A-D$ grades (see section III.A) into a numeric and continuous scale. We assigned equal weights and defined the grades as follows: $A=100, B=66, C=33, D=0$. This approach has been shown to serve as a good approximation of a continuous scale when analyzing ordinal data (Backhaus et al. 2016). In the aggregation process, we assumed equal weights between sources for each category and we treat each single source as equally important.

As resilience is a latent property of a system, and is not revealed until after an event, the significance of the sources cannot be correlated to outcomes until a flood event occurs. Until such time as this data is collected, we rely on the content or face validity of the 88 sources. The face validity includes extensive reviews by experts and pilot tests in communities in Mexico and Peru (see Keating et al. 2017). Before more formally exploring the data here, we assessed the structural model with a principal component analysis and tested the internal consistency with Cronbach's alpha. Both methods suggest a good internal consistency and structure of the sources for the FRMC tool (Laurien et al. 2019).

The descriptive statistical analysis applied to analyze the FRMC according to different lenses provides a purposive method for investigating the relationship between underlying socioeconomic conditions and flood resilience (see also Campbell et al. 2019, Laurien et al. 2019). We compare the means across settlement types with nonparametric tests (Mann-Whitney test and Kruskal-Wallis test). Tables A2.1 to A2.21 show the statistical results of using such tests, while Tables A3.1 to A3.10 provide the most relevant results in terms of their significance level.

\section{RESULTS}

In this section, we present key insights from our analysis of flood resilience data in five Asian countries. While community flood resilience is multifaceted, locally specific, and in many other ways contextually unique, there are also many similarities that can be systematically assessed to identify common resilience patterns. For this, we analyze data on the socioeconomic characteristics of the communities to identify the most relevant community characteristics (analyzed variables are outlined in Table 1) and link these to the community resilience capacities as measured by the FRMC (source grades). By utilizing the FRMC, we can assess not only the strengths and weaknesses for flood resilience (or risk reduction) but also how community development is interdependent with flood resilience for selected themes (as shown for waste management and assets and livelihoods). 


\section{A. Differences by Settlement Type}

Settlement type (rural, peri-urban, and urban) was found to be the most significant factor for clustering the communities in our sample into types. Below, we outline how flood risk, socioeconomic conditions, and finally flood resilience vary according to the three settlement types.

\section{Flood Risk}

We first explore what the data tells us about the history of floods in the communities in our sample (a proxy for flood risk) vis-à-vis settlement type. Critically, we know that many smaller, but no less locally devastating, disasters in Asia have not been monitored and reported, particularly in rural areas (UNISDR 2018). Our analysis shows that the reported flood impact history of rural communities is significantly different from urban and peri-urban communities.

Rural communities experienced on average three severe floods in the decade prior to data collection during 2016-2017, while peri-urban communities experienced at least one severe flood event, and one in every five urban communities in our sample experienced one severe flood event in the last 10 years. ${ }^{2}$

We also collected information on the length of time it took households to recover financially from past flood events. It is important to note that recovery time is not only dependent on the size of the flood, but also on household and community coping and recovery capacities and strategies. As shown in Table 3, we find that rural and peri-urban communities are slower in terms of financial recovery than urban communities.

Table 3: Financial Recovery Time from Last Severe Flood

\begin{tabular}{lc}
\hline Settlement Type & $\begin{array}{c}\text { Financial Recovery Time } \\
\text { (weeks) }\end{array}$ \\
\hline Rural & 27.0 \\
Peri-urban & 18.0 \\
Urban & 7.5 \\
\hline
\end{tabular}

Note: Based on a study of 40 rural communities with an average population of 1,000 people; 24 peri-urban communities with an average population of more than 8,000 people; and 24 urban communities with an average of 4,000 people. Source: Authors' own.

\section{Socioeconomic Conditions}

In addition to differences in flood risk (as shown via the reported flood history proxy), we also find significant differences in socioeconomic conditions in the three community settlement types in our sample. Four socioeconomic variables are found to most closely define the socioeconomic conditions in each settlement type group of communities (see Table 4).

2 "Severe" is defined as floods that were classified as "exceptional" or "catastrophic" by communities. "Normal" and "significant" floods were not found to show any detectable impact in our dataset, leading us to infer that communities are somewhat adapted to these impacts. 
There are a number of results that highlight the social and economic vulnerability of rural communities, which can be observed in Table 4. The education rate shows only one-fifth (20\%) of adults in rural communities have completed high school. In urban communities, $32 \%$ of adults have completed high school, and in peri-urban communities, 39\%. The proportion of households that are considered ethnic, religious, or otherwise identified minorities, and the proportion of female-headed households, are also significantly higher in rural communities compared to urban and peri-urban communities.

Table 4: Settlement Type Results for Socioeconomic Characteristics

(\%)

\begin{tabular}{lcccc}
\hline Settlement Type & Education Rate & Poverty Rate & Minorities Rate & $\begin{array}{c}\text { Female-Headed } \\
\text { Household }\end{array}$ \\
\hline Rural & 20 & 38 & 57 & 21 \\
Peri-urban & 39 & 17 & 14 & 13 \\
Urban & 32 & 4 & 17 & 3 \\
\hline
\end{tabular}

Notes: See Table 1 for definitions of each characteristic.

Source: Authors' own.

\section{Resilience Measurement Results}

Next, we analyze the performance of the communities in the sample against the 88 sources of resilience (Figure 2). The most frequent grade-accounting for $40 \%$ of all sources across the communities - is the second lowest, $C$. On average, 6 out of the 88 sources were assessed to be at Alevel standard, and 19 at B-level standard. This indicates a significant gap in community flood resilience investment across the region.

\section{Figure 2: Distribution of Flood Resilience Scores by Settlement Types}

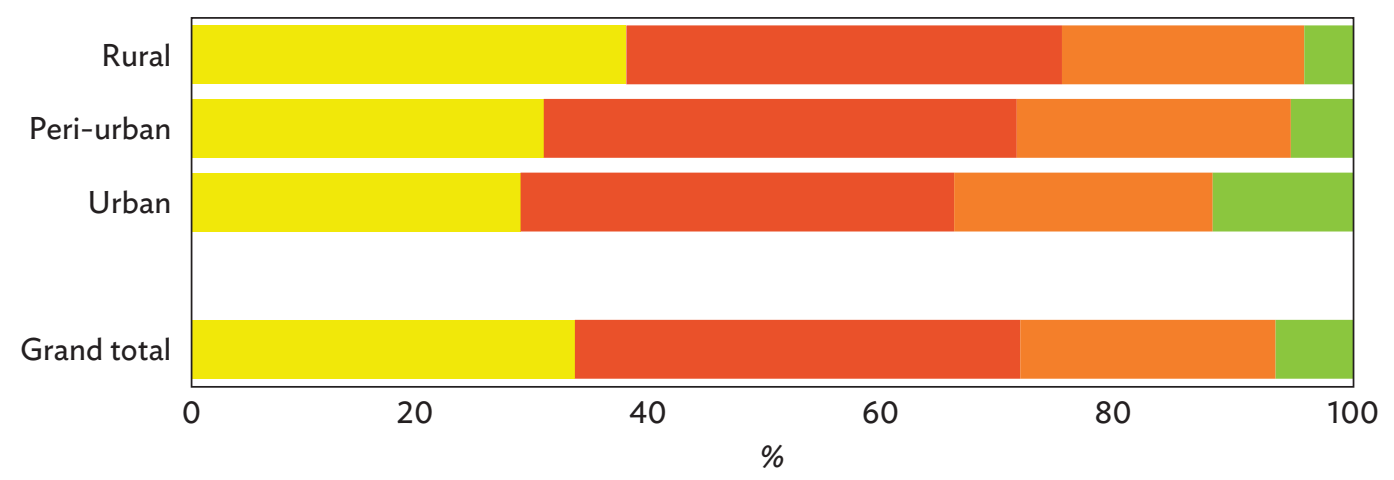

Best practice in community resilience $(A)$

Good resilience standard, no immediate need for improvement (B)

Deficiencies, room for visible improvement (C)

Significantly below good standard, potential for imminent loss (D)

Source: Authors' own. 
While all communities need improvements in their flood resilience capacity, urban communities fare slightly better than rural and peri-urban communities. Rural (peri-urban) communities lack in $75 \%$ (71\%) of the sources (receiving a C or D grade), with only $4 \%$ (5\%) being at best practice $(A)$, indicating significant potential for improvements in the long run. Urban communities, on the other hand, have $34 \%$ of sources assessed at a good standard (A or B), with $12 \%$ at best practice for managing risk (A).

Settlement type is not the only factor that influences community-level resilience to flooding. Our analysis shows that socioeconomic factors such as education level and type and diversity of livelihood strategies are closely related to flood resilience capacity. Approximately $20 \%$ of flood resilience sources within the framework overlap with community development (the other $80 \%$ being more flood specific). This overlap between community flood resilience and general community development indicators such as the education sector, transportation, and food supply systems could signal significant potential for investments with wide cobenefits.

\section{B. Analyzing Strengths and Weaknesses}

In this section, we shed light on how communities can make decisions to build capacity in flood resilience. It is challenging to make good and robust decisions to build community flood resilience, especially as generalized evidence is usually lacking. However, if patterns emerge across many communities, the findings can help to advocate for investments in effective solutions. For instance, at a general level, our analysis of data across all communities has identified that human capital is often graded highest, while financial capital is graded very low. These types of findings can inform decisions for DRM, resilience, and well-being by helping to prioritize intervention investments into community or regional programs that, for example, leverage human capital and/or select cost-effective financial coping strategies.

By analyzing the data from the FRMC tool according to the "themes" lens, we find that across the communities in our sample, education, transportation, and water supply are the biggest strengths (Figure 3). This may be because these areas tend to be the traditional foci of community development investment. We also identify several significant flood resilience gaps across settlement types. Environment and governance are the biggest gaps for urban communities, while food security and waste management are the biggest challenges for rural communities. Peri-urban communities find waste management and environmental issues challenging. Interestingly, compared to rural and periurban communities, urban communities are significantly stronger for all themes except for governance, health, and environment (for details on the statistical analysis, see Appendix 2).

Similarly, interesting evidence is found when results are analyzed by the stages of the DRM cycle (see section III.B). When we compare means across settlement types, we see that rural and urban communities are significantly different when it comes to their prospective risk reduction capacities (Figure 4). The Kruskal-Wallis test shows overall significant differences between settlement types $(H=11.742, p=0.03)$ and highly significant differences between rural and urban communities if adjusted by the Bonferroni correction $(H=-22.567, p=0.02)$. When it comes to coping strategies, urban communities are also significantly different from rural and peri-urban communities; the KruskalWallis test identifies overall significant differences $(H=32.079, p=0.00)$ and highly significant differences between urban and rural communities $(H=-22.567, p=0.02)$ and urban and peri-urban communities $(H=-23.917, p=0.04)$ if adjusted by the Bonferroni correction. On the other hand, we see relatively high results for rural and peri-urban communities for corrective risk reduction, but the absolute means do not show a significant difference by the Kruskal-Wallis test. For crisis preparedness, we see absolutely and relatively equal results for all settlement types (see Appendix 3). 
Figure 3: Theme-Specific Strengths and Weaknesses across Settlement Types

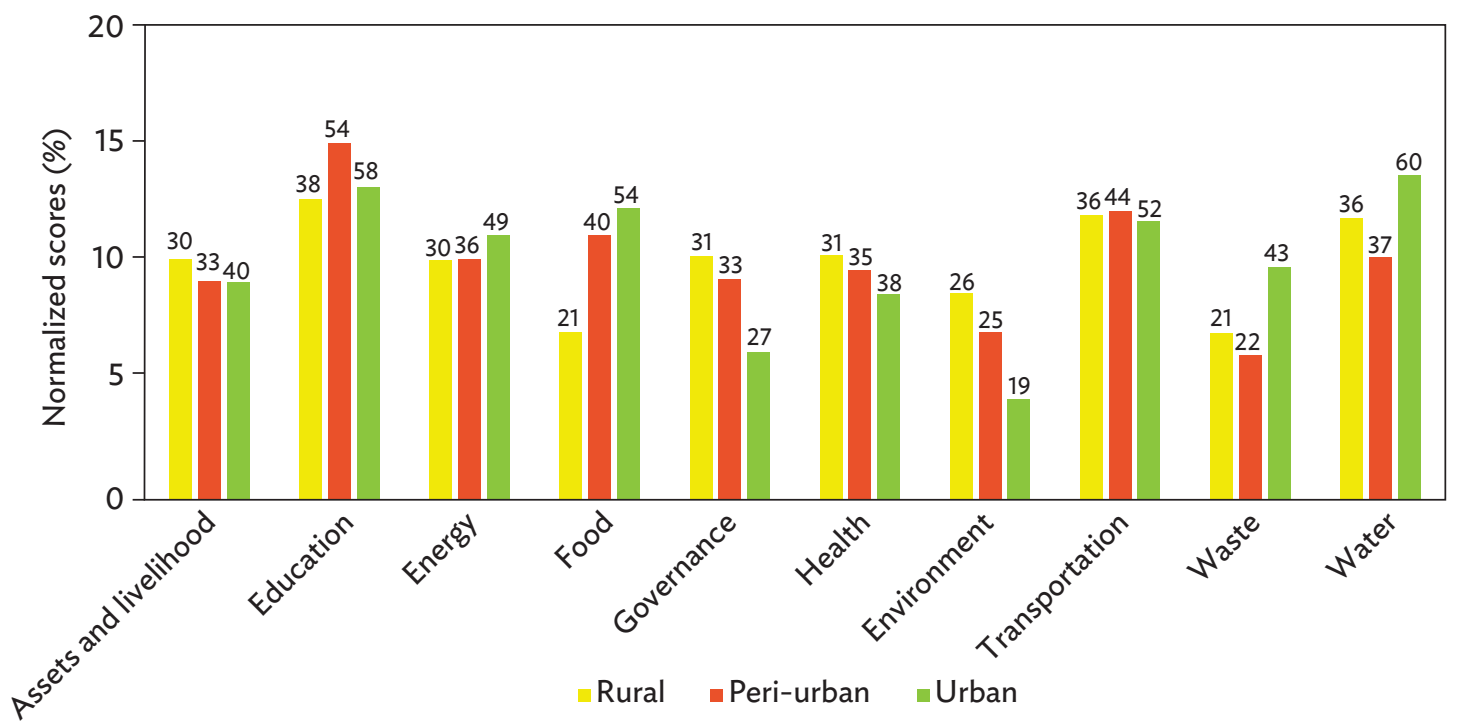

Notes: The y-axis shows normalized scores and the numbers at the top of each bar show absolute values. The normalized scores allow comparison across themes and between settlement types, as most of the sources are graded relative to their neighborhoods. Source: Authors' own.

Figure 4: Disaster Risk Management-Specific Strengths and Weaknesses across Types of Communities

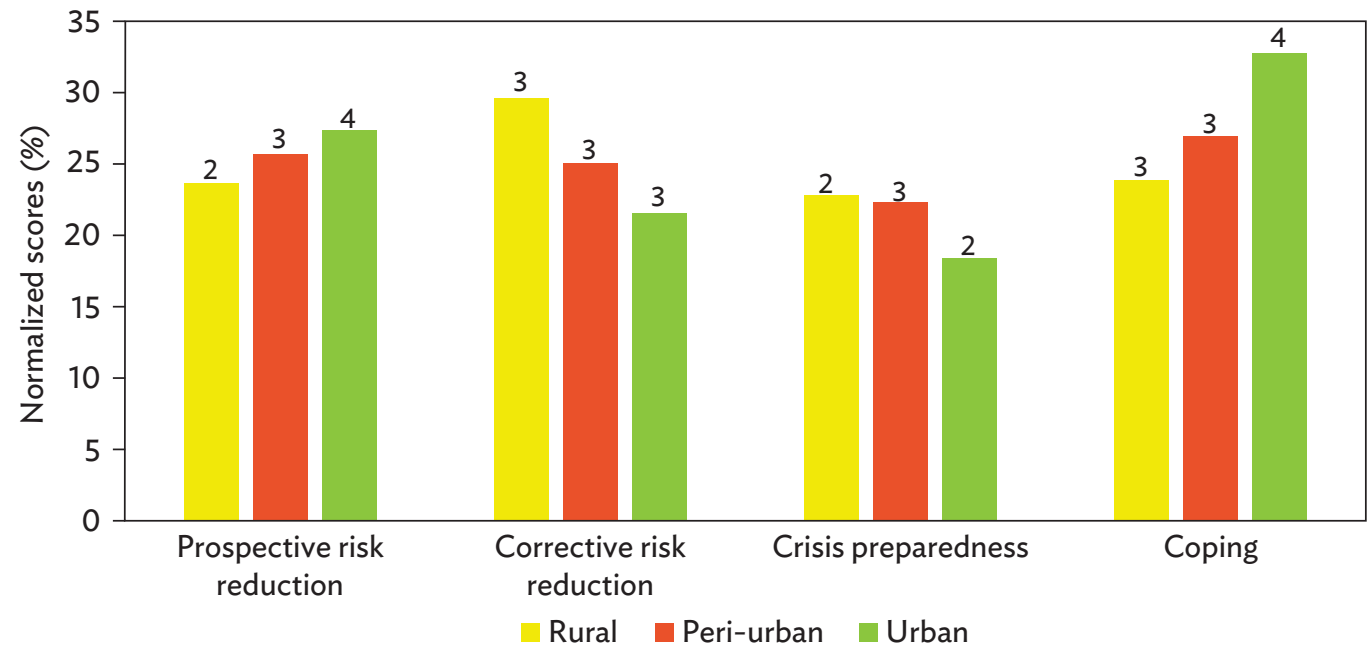

Notes: The $y$-axis shows normalized scores. The numbers at the top of each bar show total absolute values. Source: Authors' own. 
One interpretation of this outcome may have to do with the relative complexity of rural and peri-urban communities vis-à-vis urban communities, and the speed at which development is occurring. Compared to urban communities, rural and peri-urban communities are relatively less complex, and development and population change occur at a slower rate. These community system properties may mean that:

- Prospective risk reduction is stronger in urban communities than in rural and/or peri-urban ones because it relates to new development. New development is occurring in urban communities at a much higher rate than in rural and peri-urban communities. Hence, rural and peri-urban communities do not have the same avenues to consider how new development is building more risk into the system, simply because there is not much new development occurring. Furthermore, the relative poverty of rural communities may mean that taking a longer-term perspective is outside the scope of community members struggling to meet basic, immediate needs.

- Corrective risk reduction is relatively stronger in rural and peri-urban communities than in urban ones, because it relates to taking physical measures in homes and businesses (such as flood risk reduction improvements) and on the landscape (such as dykes or reforestation projects). In urban communities, households generally live in smaller dwellings that they cannot retrofit for structural reasons or because they are leaseholders rather than owners. Similarly, urban communities often have less capacity to invest in larger scale protections, such as levees or urban greening, because they lack the physical space, or the hazard source (river, coast) is managed by an outside authority. While the statistical results do not prove a highly significant difference, the qualitative interpretation still obverses notable deviations between the settlement types.

- Crisis preparedness is - in absolute and relative terms - the weakest property across all three settlement types. The small differences between rural, peri-urban, and urban communities might indicate that flood resilience planning is not sufficiently integrated in community governance plans (e.g., coordinating emergency strategies in regard to urban planning).

- Flood resilience capacity in the form of postflood coping is the strongest of all the stages of the DRM cycle, although there are also significant differences between settlement types. In urban communities, coping strategies are significantly stronger than in rural and periurban communities because people are generally wealthier, have higher livelihood diversification, and are less dependent on the local environment (natural and social) for their livelihoods. In rural and peri-urban communities, people are relatively poorer and, as such, less able to cope. In addition, their incomes are largely agricultural, which means they are highly exposed to local flooding.

Table 5 shows the average scores assigned to the sources that fall into each theme-DRM cycle pair. This cross-tabulation allows us to examine the strengths and weaknesses across the themes with reference to the DRM cycle, and across the three settlement types. Note that theme-DRM cycle pair has an assigned source out of the 88 sources of resilience.

The education theme scores the highest average grade; one reason for this may be that education is a traditional focus of community development work, so there has been marked investment in this area. By looking at lower scores, we can identify which themes are in need of further investment. Based on the results from Table 5, we selected two themes to explore in detail below. Firstly, we selected the waste management theme, because it has one of the lowest average grades of all the elements considered in the FRMC framework. Secondly, we selected assets and livelihoods because this theme is highly correlated with the steps of the DRM cycle. 


\section{Table 5: Analysis of Flood Resilience Scores across Themes and Steps of the Disaster Risk Management Cycle}

\begin{tabular}{lccccc}
\hline Themes & $\begin{array}{c}\text { Prospective } \\
\text { Risk Reduction }\end{array}$ & $\begin{array}{c}\text { Corrective Risk } \\
\text { Reduction }\end{array}$ & Coping & $\begin{array}{c}\text { Crisis } \\
\text { Preparedness }\end{array}$ & Average Scores \\
\hline Assets and livelihoods & 41 & 41 & 25 & 20 & 34 \\
Education & 48 & & 75 & 23 & 37 \\
Energy & 46 & & 43 & 28 & 35 \\
Food & 32 & & 46 & 29 & 31 \\
Governance & 28 & 33 & 35 & 33 & 34 \\
Life and health & 32 & 33 & 35 & & 24 \\
Natural environment & 23 & 27 & & 20 & 42 \\
Transport and communication & 45 & & 51 & 10 & 27 \\
Waste management & 28 & & 33 & 26 & 43 \\
Water & 40 & & 52 & 29 & 34 \\
\hline Average score & 34 & 35 & 37 & & \\
\hline
\end{tabular}

Note: Each figure in the matrix is the average score of the sources (indicators) across the sample of 88 communities that are assigned to the two groups, for example, 41 is the average score of the sources (indicators) assigned to "assets and livelihoods" in the themes lens and "prospective risk reduction" in the disaster risk management cycle lens.

Source: Authors' own.

Furthermore, both the assets and livelihoods and waste management themes have high complexity. Complexity in this sense refers to the fact that tackling the flood resilience of the waste management system in a community, or the community's system of assets and livelihoods, requires a holistic approach integrated with the community's wider development agenda. Decisions made in regard to these themes can have long-term and often irreversible impacts on community development. In this way, these themes are highly connected to development and thus the core purpose of taking a resilience approach. Exploring-and ultimately building-resilience within these complex themes contributes understanding of the complex, dynamic interactions that drive development and DRM outcomes.

\section{Waste Management}

Our first example comes from the "waste management" theme, which contains sources of resilience that, when working at good standard, ensures that household and business wastes (sewage and garbage) do not cause problems in the event of a flood. Uncontained waste in a flood event can lead to cascading effects and is a source of indirect losses and damages. A dysfunctional or poorly managed waste management system will create waste problems (backlog and overflow) and ultimately lead to environmental contamination and health problems. During a flood event, waste can reduce or block the effects of emergency responses and recovery activities. Waste can even worsen the flood hazard itself, for example, rubble and debris blocking a canal can result in more severe flooding.

We used the DRM cycle lens to explore the issue of waste management and community flood resilience. Our data show that when it comes to waste management and floods, communities struggle with both short- and long-term planning. Neither the crisis preparedness measures (such as strategies to maintain or quickly resume waste collection and disposal services), nor long-term prospective risk 
reduction measures (such as the functioning and equitable waste collection and disposal services) are well established in communities in our sample. Critically for this theme, understanding the relationship between short- and long-term strategies can reduce complexity and aid in investment decisionmaking. While, in general, preparedness strategies tend to be easier to implement because they are narrowly focused (less complex); it is virtually impossible to prepare a waste management system for floods if it is not already well managed.

Therefore, an intervention focused on flood resilience and waste management systems would be centered on establishing or improving the system in nonflood times, and then explicitly considering its functioning in the event of a flood. Naturally, it would also include a community-focused element to increase awareness of the risk of contamination from improper disposal of waste. Realizing this in practice requires a holistic approach that includes multiple stakeholders at multiple levels-from community members and businesses right up to regional governments. By taking such an approach, a waste management system can be established that benefits the community in normal times and does not cause negative impacts to health and the environment in the event of flooding.

\section{Assets and Livelihoods}

The second example that shows what can be learned by exploring community disaster resilience data, in this case from the FRMC, relates to the theme "assets and livelihoods." Assets and livelihoods are those that relate to the risks from floods to community and household physical and financial assets, and livelihood strategies. Our analysis found that the level of resilience of assets and livelihoods has long-term consequences, not only for development, but also for a whole host of other community flood resilience sources. Therefore, enhancing resilience of assets and livelihoods has flow-on effects, potentially activating or magnifying resilience in other areas.

When exploring the resilience of assets and livelihoods the first thing to note is that, as discussed above, compared to rural and peri-urban communities, urban communities have more diverse livelihood strategies. However, because these communities are more concentrated and complex, there are also more challenges for reducing risk.

We again use the DRM cycle to identify that the biggest weakness in regard to assets and livelihoods is coping; this finding contrasts with all other themes. Overall, strategies to cope with negative impacts for assets and livelihoods have the lowest resilience capacity across themes (coping strategies scored 25 compared to an average of 37 [see Table 5]). One explanation for this finding may be that coping strategies for assets and livelihoods are largely financial, and financial capital is weak across the community sample.

For example, the sources "income continuity planning for households" and "financial continuity strategies for businesses" are important coping measures to build livelihood and business resilience. Based on household surveys (number of households is equal to 4,332), we found that less than a fifth of rural households have a plan to maintain income in the event of a flood. In contrast, more than two-thirds of urban households do have such a plan. This corresponds with the finding that after a flood event, $60 \%$ of people in rural communities experience loss of income, while in urban communities, more than $75 \%$ have no loss of income after a severe flood. In addition to the higher frequency of floods in the rural communities in the sample, we speculate that this finding stems from the place-dependent nature of livelihoods in rural communities and the lack of diverse livelihood options. In rural communities, households are dependent on the agriculture sector with their agricultural lands typically located in the vicinity of the community. This means that if the community 
experiences a flood, it is highly likely that the source of their livelihood will also be affected. In contrast, in urban communities, people more often reside away from their livelihood source, and if their livelihood is affected, they have far more options for alternatives.

We find strengths in regard to knowledge and awareness about flood-exposed areas. In fact, this is one of the highest graded sources of resilience (10th in urban, 1st in peri-urban, and 2nd in rural communities). This finding is not unexpected, since knowledge and awareness interventions are necessary primary conditions for more substantive action and are relatively easily implemented.

Regarding corrective risk reduction, we look at the source "communal flood controls." Communal flood controls are community-scale infrastructure such as dykes or upstream reforestation that protect the community's assets by reducing current flood risk. The source communal flood controls is ranked as the 13th strongest source in rural communities, but the 40th in urban, and the 48th in peri-urban communities. This could be because increasing both gray (engineering based) and green (ecosystem based) protection infrastructure in urban areas is challenging due to space constraints magnified by migration pressures.

Turning finally to prospective risk reduction to protect assets and livelihoods, we find that communities are better able to understand future risks than they are able to actively release resources to put this knowledge into practice (e.g., Basin Level Flood Controls). Digging a little deeper into these findings, our data show that rural communities struggle more to identify future risks than do peri-urban and urban communities.

\section{CASE STUDIES}

In this section, we present two case studies of clusters of communities, the first from Indonesia and the second from Afghanistan. We selected these community clusters because they differ in several ways, capturing different contexts across Asia.

\section{A. Urban Indonesia}

Here we consider 16 communities located in Semarang City, Indonesia, where the FRMC tool was applied by the NGO Mercy Corps. Semarang, with a population of approximately 1.6 million people, is crisscrossed by 21 rivers. Thirty-five percent of the city is in low-lying and coastal regions; hence, Semarang is highly vulnerable to floods. Semarang experiences significant immigration from smaller cities and rural areas, rapidly increasing the population. Climate change is thought to be magnifying flood risk, via sea-level rise, high waves, and more intense rainfall and storm surge (Semarang City 2016, Harwitasari and van Ast 2011).

The population in the 16 communities obtains their income via work in the production and service sectors, with the agriculture sector playing only a minor role. A vast majority (83\%) of the residents are "middle income" by Indonesian standards, with only a very small proportion of community members living below the national poverty line. In the last 10 years, the communities have suffered several small flood events.

Figure 5 shows the flood resilience capacity by the five capitals at both baseline and endline measurements. At baseline, human and physical capital perform significantly better than the other three capitals. Human capital received an average score of 57 on a scale of $0-100$, and physical capital received an average score of 48 on the same. Overall, communities in Semarang City struggle to build 
capacity in social (baseline average 30) and natural capital (baseline average 32). Financial capital (baseline average 39) shows a diverse picture within capitals of stronger and weaker sources. Between baseline and endline measurements, grades improved in all capital groups except for natural capital, which showed a movement toward the center; compared to the baseline, the endline had less $D$ grades but also less $B$ and $A$ grades. This can possibly be attributed to improved understanding of the natural capital sources on the part of assessment teams.

Figure 5: Distribution of Grades for 88 Sources of Resilience in Five Types of Capital, Urban Indonesia (Semarang City)

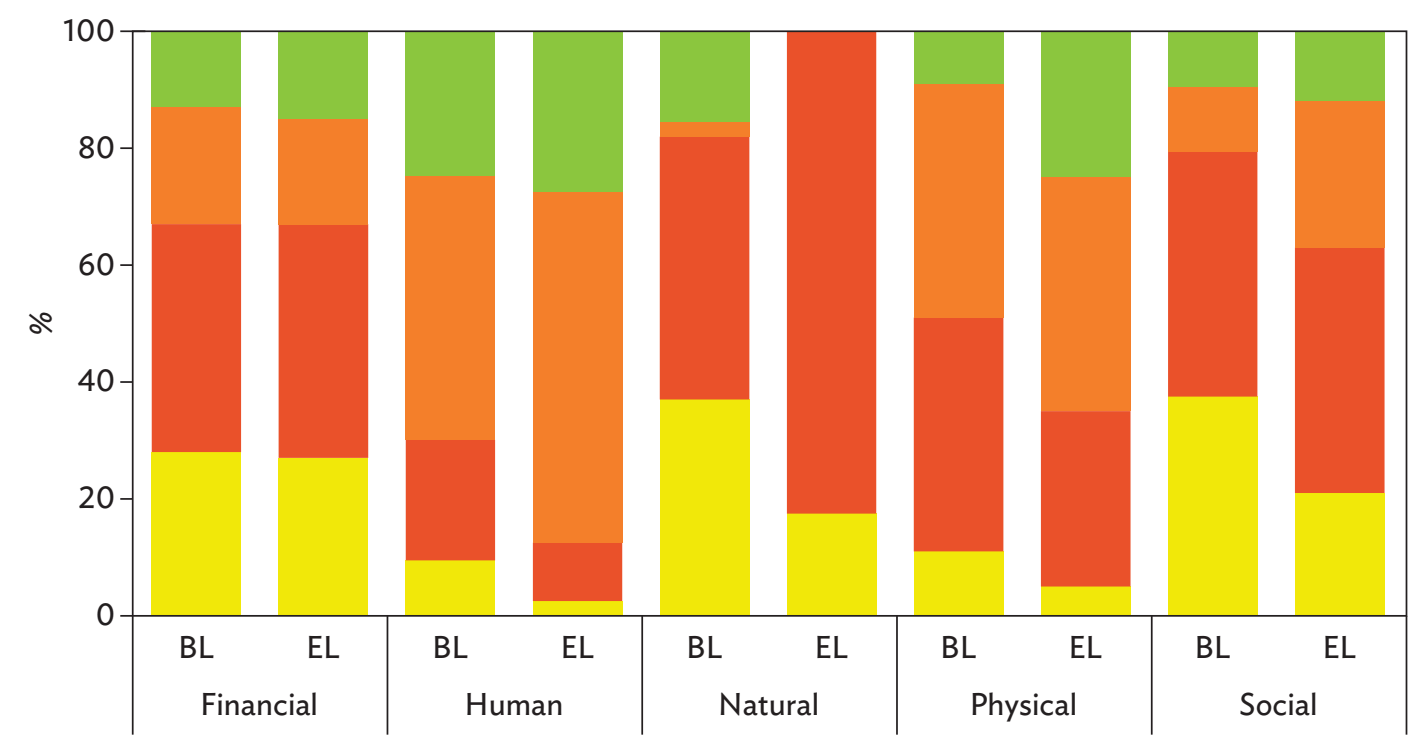

$\mathrm{A} \square \mathrm{B} \square \mathrm{C} \square \mathrm{D}$

$\mathrm{BL}=$ baseline, $\mathrm{EL}=$ endline.

Source Authors' own.

Because the 16 communities are all close to one another along the same river, their flood risk is interdependent. Mercy Corps Indonesia, together with local NGO Initiative for Urban Climate Change and Environment, worked with the communities to establish community-based DRM documents and develop community action plans. The FRMC data was a critical input into the community action plans and in the intervention prioritization process. This process involved stakeholder workshops to undertake community flood risk mapping, discussion of FRMC results, prioritization of key issues, and identification of priority actions. The FRMC results were presented in an accessible way. Specifically, the sources that were graded $C$ or $D$ (requiring imminent attention) were discussed in the context of the themes categorization. Next, the rationale for each grade was discussed to convey the reasons behind the weakness. This process was discursive, with community stakeholders encouraged to probe and challenge the findings. The process also provided the opportunity for the community to share further information.

In Figure 6, we see one output of this process: weak sources prioritized for action and grouped according to their urgency and importance. Next, workshop participants identified actions to address these weaknesses and then prioritized these according to numerous codefined criteria. 
Figure 6: Decision-Making Assessment in Terms of Urgency and Importance for Flood Resilience Implementation Process

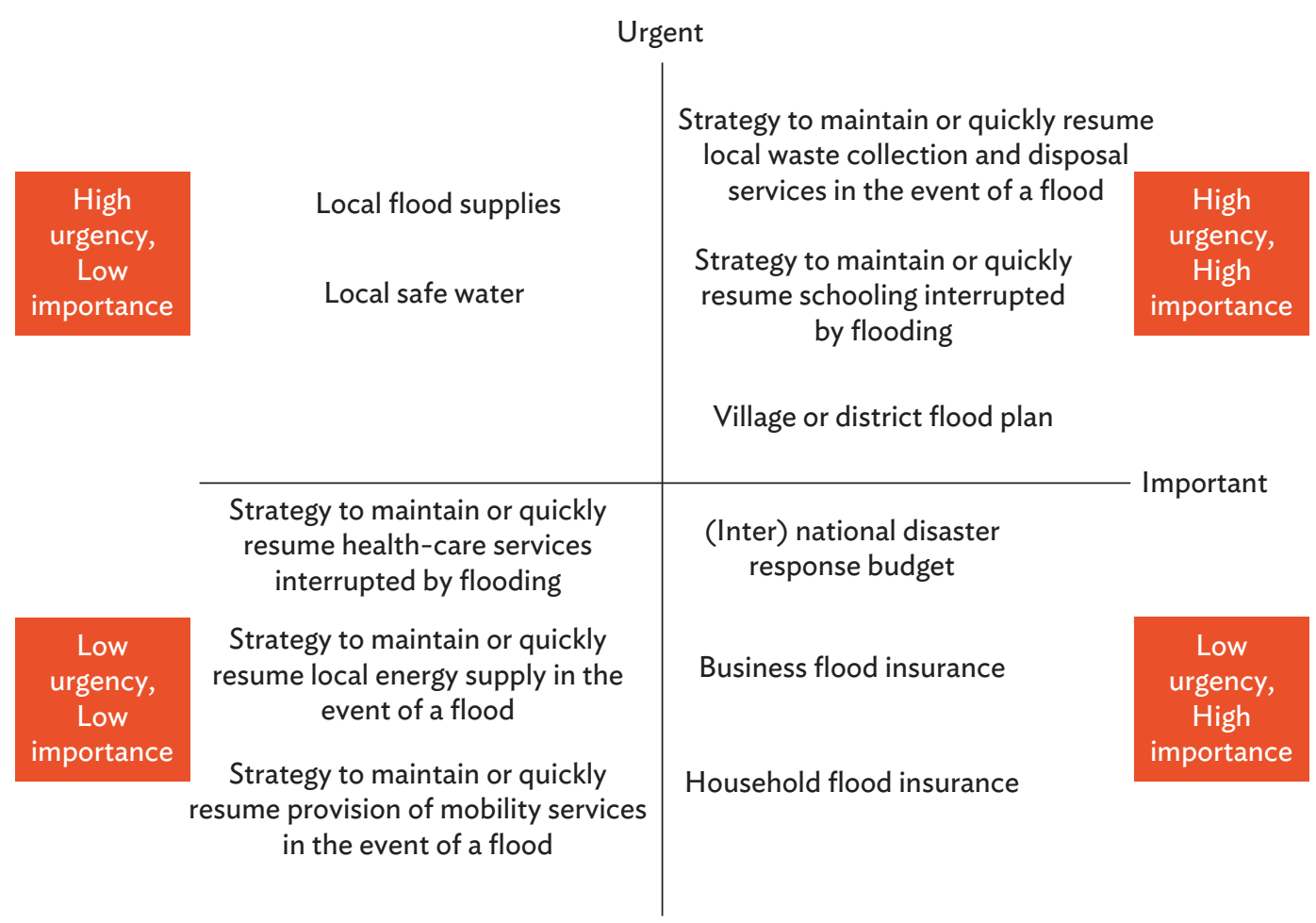

Source: Mercy Corps Indonesia. 2016. "Application of FRMT to Enhance Community-Based Flood Resilience in Semarang City, Central Java, Indonesia.” Zurich Flood Resilience Project (personal consultation). Zurich. components:

The result of this process was a flood resilience implementation plan with two major

(i) Integrated flood information sharing system. The FRMC process found limited social participation in flood risk management, lack of formal emergency services, poor strategies for delivery of actionable information, social exclusion, and weak community sharing mechanisms. This solution was designed to address these weaknesses by establishing an integrated flood information system, consisting of an information tool to reach people in at-risk communities.

(ii) Community disaster preparedness groups. The FRMC process found an absence of community representative bodies for flood risk management, limited social participation where structures did exist, and limited coordination mechanisms across communities. This solution was designed to establish community-level flood preparedness groups and committees that would coordinate both internally and with regional disaster management agencies.

Furthermore, the results from this process were shared with key city stakeholders, including planning and development authorities, who are responsible for city programming and community budget allocation. 


\section{B. Rural Afghanistan}

NGO Concern Worldwide applied the FRMC in 12 communities in rural Afghanistan. Afghanistan has experienced considerable civic unrest for many years. Over $50 \%$ of the population live below the poverty line (CIA World Factbook 2018), and it has an extremely low human development index ranking (UNDP 2018). Afghanistan is also highly vulnerable to natural hazards, including floods. Floods are the most frequent natural hazard in the country. They affect approximately 100,000 people each year and cost the poor economy hundreds of millions of dollars (GFDRR 2017).

These communities had the lowest flood resilience scores in the dataset. Located in the Yawan district in eastern Afghanistan, these communities are home to approximately 13,000 people. It is mountainous and relatively sparsely populated. Almost all residents are poor or very poor farmers, practicing unsustainable cultivation on marginal land prone to extreme weather. Seventy percent of people depend on agriculture for their livelihoods, and almost $70 \%$ are living below the national poverty line. Flash floods and mudslides frequently block roads, rendering communities inaccessible to vehicles. All communities in this sample were impacted by an extreme flood event in the last 10 years.

Figure 7: Distribution of Grades for 88 Sources of Resilience, in Five Types of Capital, Rural Afghanistan

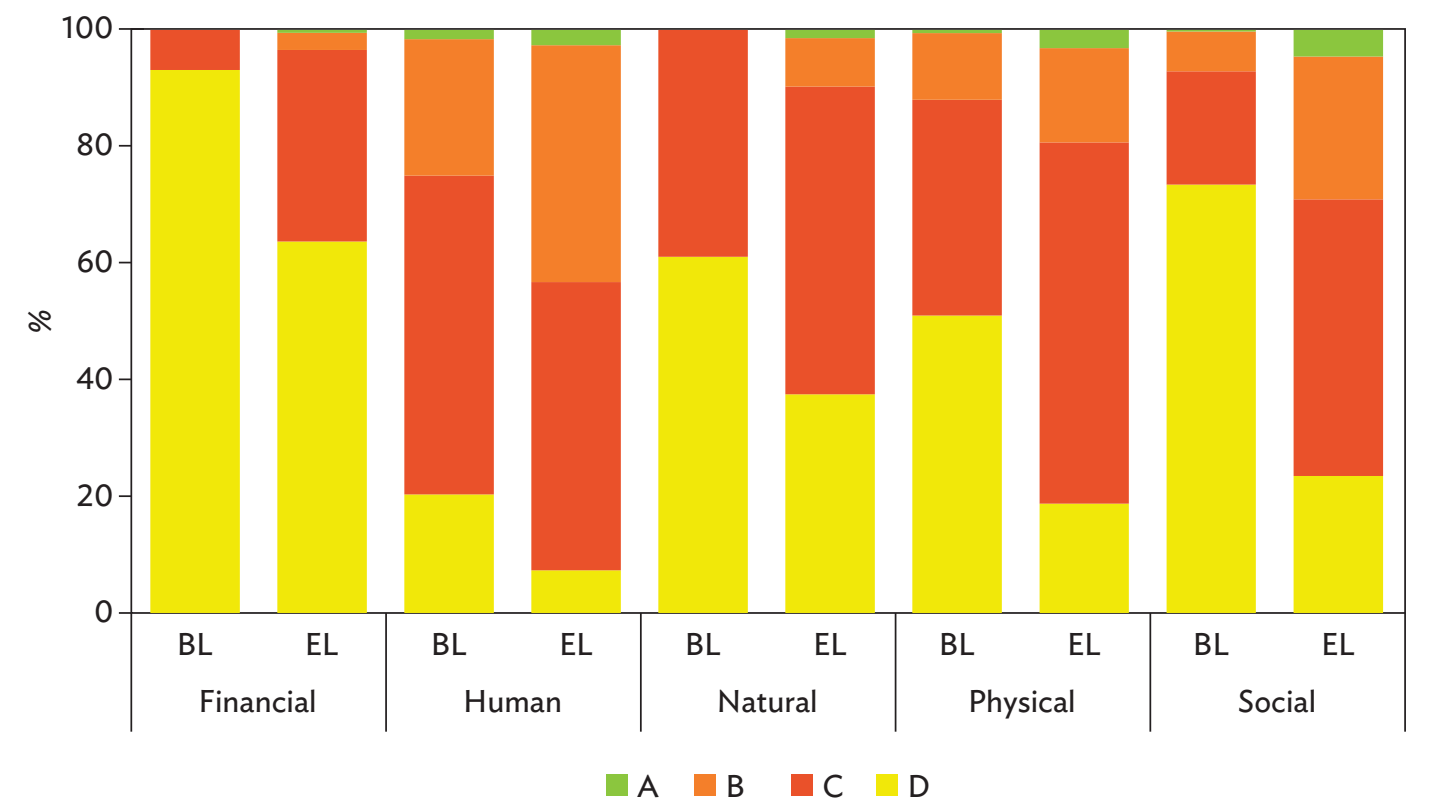

$\mathrm{BL}=$ baseline, $\mathrm{EL}=$ endline.

Source: Authors' own.

The FRMC data on the communities in Afghanistan revealed multiple weaknesses, as indicated by the very low grades shown in Figure 7. The NGO team looked at the data in different ways to identify key systemic issues. The Concern Worldwide team, working with the Afghan communities, analyzed the data and identified potential for improvements in community-driven flood mitigation infrastructure, based on (i) underinvestment in these protections, especially in regard to critical infrastructure, such as roads, coupled with (ii) relatively strong human capital that could be leveraged (see solution "small-scale mitigation techniques" below). 
By using the themes lens, the data revealed significant issues related to food and water security after a flood, and that these issues stem from energy insecurity. These issues severely hamper capacity to cope and recover from floods, which was also observed in the data. Also impacting coping capacity was lack of access to credit and insurance for farmers and a general lack of communal and household financial safety nets. Lack of health care and schooling were also identified as key challenges affecting the communities.

The NGO identified which weaknesses were relevant to the context and within the capacity of the organization to deliver. Once the final list of key focus areas had been identified, solutions were suggested and then compared against a number of criteria, including whether they were gender sensitive, sustainable, and cost-effective. Viable solutions were then subjected to a participatory CBA process in each community, where community members drove prioritization. The participatory CBA process, together with the NGO's feasibility studies, resulted in the final intervention plan, which included the following elements:

(i) Small-scale mitigation techniques. In response to limited investment in flood risk reduction, this intervention was designed to put in place small-scale flood risk reduction infrastructure. These strategies are managed by community disaster management committees and use locally sourced materials and existing community knowledge to ensure the sustainability of the intervention beyond the life of the project.

(ii) Mainstreaming flood risk into community development planning. Community development initiatives are weak in several areas, including in relation to disasters. Concern Worldwide used the outputs from the FRMC to enhance flood risk awareness within local community development councils and incorporate flood resilience considerations into local development initiatives.

(iii) Solar technologies for food and water security, gender equality, and environmental sustainability. As discussed above, communities in this region are highly vulnerable to disaster-induced (transitory) food and water insecurity when energy for cooking and boiling water becomes unavailable. At the same time, collecting firewood for wood stoves removes local vegetation and thereby increases flood risk. Finally, women and girls who cook on woodfire stoves suffer negative health impacts from breathing in smoke and accidental burns. To combat this, Concern Worldwide distributed solar cookers and solar dryers to the poorest and most vulnerable households in the study communities.

\section{CONCLUSIONS AND RECOMMENDATIONS}

This paper aimed to outline the significance of a holistic concept of community disaster resilience for tackling the systemic challenges at the heart of the development-disaster nexus in Asia. It then explored the potential for measuring community disaster resilience, reporting on findings from a largescale measurement endeavor of 88 communities in five Asian countries. Analysis of community-level data generated insights about the strengths and weaknesses in different community types. These insights highlight the importance of investing in community disaster resilience and signpost where investment could be most effective in different communities. Our community case studies show how measuring community disaster resilience can lead to novel and systemic investments on the ground that bring to life the potential of resilience by tackling the underlying drivers of increasing risk. 
Our analysis of the data from the 88 communities measured by the FRMC shows how these types of meta-analyses can inform national and regional investments. We found significant differences in community flood resilience across Asia depending on the settlement type, with rural, peri-urban, and urban areas having distinct profiles. Communities in rural areas of Asia are bearing the costs of floods more frequently and more intensely than in urban, and to a lesser extent peri-urban, areas. Effects are devastating and widespread, with $90 \%$ of rural households having suffered significant damage to assets and/or loss of life in the last decade. Not only this, but rural areas take much longer to recover. Since disasters can stifle development, it is conceivable that disasters are playing a role in stifling economic growth and improvements in well-being in rural areas of Asia. Hence, there is a need to invest in community disaster resilience, particularly in rural areas. Without such investment, disasters will continue to derail development gains, and in rural areas, act as push factors driving people toward rapidly expanding cities.

Also, at the regional level, data showed significant gaps in community-level resilience to flooding across Asia. While we found that settlement type and general development level (as proxied by indicators such as education) were significant for flood resilience capacity, there is plenty of variation even among communities with very similar profiles. This reveals that there is much potential to enhance community flood resilience in the short and medium term with targeted interventions.

The meta-analysis of community-level data allowed us to explore the relative strengths and weaknesses of different community types across the DRM cycle. We found that the higher complexity of urban communities compared with rural and peri-urban communities meant that urban communities may benefit from interventions that tackle crisis preparedness and corrective risk reduction-key challenges in these areas. Meanwhile, rural and peri-urban communities could be encouraged to take a longer-term view and consider prospective risk reduction and supported to cope better after disaster events. Good coping strategies are particularly important for rural communities, because they reduce the indirect impacts of floods on longer-term development outcomes.

Our deep dive into the waste management theme illustrated the importance and challenges of tackling multifaceted community systems. While challenging, addressing how waste management systems perform in the event of a flood has the benefit not only of responding to this issue, but also of building the capacity of local stakeholders and the community to understand the linkages between disasters and development. Putting resilience thinking into practice requires bringing multiple, diverse stakeholders to the table and has the potential to shift thinking around DRM and development to highlight connections.

The capacity to undertake corrective and prospective risk reduction in relation to assets and livelihoods is central to disaster resilience, because it actively tackles a key underlying driver of increasing disaster risk: development that inadvertently increases exposure and vulnerability. Undertaking this risk management work requires a long-term and transformative approach and complex interventions involving multiple actors (communities, businesses, governments) such as resettlement and land use planning. However, this long-term perspective is essential if Asia is to effectively manage its urbanization and population growth while maintaining and enhancing human well-being. Without such investment, disaster risk and subsequent impacts will continue to grow.

Also highlighted by the waste management theme and the consideration of prospective risk reduction in the FRMC tool is the adage "what gets measured gets managed." The performance of waste management systems in the event of a disaster and the need to engage in prospective risk reduction were not previously an issue on the radar of many of the community development and 
disaster NGOs using the FRMC tool. By including it in the framework, the Zurich Alliance brought it to the attention of the NGOs, stakeholders, authorities, and communities.

From the case studies, we found that measuring resilience at the community level can be a scaffolding upon which an organization can build a community-engagement process that results in jointly identified priority investments. The actions that organizations and communities undertake following this measurement-informed process tend to be holistic and integrated, taking a systemwide approach. This approach means that investments are more likely to succeed, be sustainable, and have cobenefits for community development. 


\section{Appendix 1}

Table A1: Sources of Resilience

\begin{tabular}{|c|c|c|c|c|}
\hline Source Name & Code & $5 C$ & DRM Cycle & Theme \\
\hline $\begin{array}{l}\text { Household financial savings that protect } \\
\text { long-term assets }\end{array}$ & $\mathrm{F} 1$ & Financial & Coping & Life and health \\
\hline Income and affordability & $\mathrm{F} 2$ & Financial & Coping & Life and health \\
\hline Communal social safety net & F3 & Financial & Coping & Life and health \\
\hline Household credit access & $\mathrm{F} 4$ & Financial & Coping & Life and health \\
\hline Business credit access & F5 & Financial & Coping & $\begin{array}{l}\text { Assets and } \\
\text { livelihoods }\end{array}$ \\
\hline Household flood insurance & F6 & Financial & Coping & $\begin{array}{l}\text { Assets and } \\
\text { livelihoods }\end{array}$ \\
\hline Business flood insurance & F7 & Financial & Coping & $\begin{array}{l}\text { Assets and } \\
\text { livelihoods }\end{array}$ \\
\hline Household income continuity strategy & F8 & Financial & Coping & $\begin{array}{l}\text { Assets and } \\
\text { livelihoods }\end{array}$ \\
\hline Household budget management & F9 & Financial & Coping & Life and health \\
\hline Continuity of business & F10 & Financial & Coping & $\begin{array}{l}\text { Assets and } \\
\text { livelihoods }\end{array}$ \\
\hline $\begin{array}{l}\text { (Inter) National disaster response } \\
\text { budget }\end{array}$ & F11 & Financial & $\begin{array}{l}\text { Crisis } \\
\text { preparedness }\end{array}$ & Governance \\
\hline $\begin{array}{l}\text { Social safety net (legislative, national } \\
\text { schemes) }\end{array}$ & F12 & Financial & Coping & Governance \\
\hline $\begin{array}{l}\text { Mitigation financing (provided through } \\
\text { public or private) }\end{array}$ & F13 & Financial & $\begin{array}{l}\text { Corrective risk } \\
\text { reduction }\end{array}$ & $\begin{array}{l}\text { Assets and } \\
\text { livelihoods }\end{array}$ \\
\hline Functioning financial market & F14 & Financial & Coping & Life and health \\
\hline $\begin{array}{l}\text { Government appropriations for } \\
\text { infrastructure maintenance }\end{array}$ & F15 & Financial & $\begin{array}{l}\text { Corrective risk } \\
\text { reduction }\end{array}$ & Life and health \\
\hline $\begin{array}{l}\text { Community development investment } \\
\text { vehicles }\end{array}$ & F16 & Financial & $\begin{array}{l}\text { Prospective risk } \\
\text { reduction }\end{array}$ & Life and health \\
\hline Conservation budget & $\mathrm{F} 17$ & Financial & $\begin{array}{l}\text { Prospective risk } \\
\text { reduction }\end{array}$ & $\begin{array}{l}\text { Natural } \\
\text { environment }\end{array}$ \\
\hline $\begin{array}{l}\text { Flood protective behavior and } \\
\text { knowledge }\end{array}$ & $\mathrm{H} 1$ & Human & $\begin{array}{l}\text { Crisis } \\
\text { preparedness }\end{array}$ & Life and health \\
\hline Personal safety & $\mathrm{H} 2$ & Human & $\begin{array}{l}\text { Crisis } \\
\text { preparedness }\end{array}$ & Life and health \\
\hline First aid knowledge & $\mathrm{H} 3$ & Human & $\begin{array}{l}\text { Crisis } \\
\text { preparedness }\end{array}$ & Life and health \\
\hline Value of education & $\mathrm{H} 4$ & Human & Coping & Education \\
\hline Flood water control knowledge & H5 & Human & $\begin{array}{l}\text { Corrective risk } \\
\text { reduction }\end{array}$ & $\begin{array}{l}\text { Assets and } \\
\text { livelihoods }\end{array}$ \\
\hline Flood exposure perception & $\mathrm{H} 6$ & Human & $\begin{array}{l}\text { Prospective risk } \\
\text { reduction }\end{array}$ & $\begin{array}{l}\text { Assets and } \\
\text { livelihoods }\end{array}$ \\
\hline
\end{tabular}


Table A1 continued

\begin{tabular}{|c|c|c|c|c|}
\hline Source Name & Code & $5 C$ & DRM Cycle & Theme \\
\hline Flood exposure management knowledge & $\mathrm{H} 7$ & Human & $\begin{array}{l}\text { Prospective risk } \\
\text { reduction }\end{array}$ & $\begin{array}{l}\text { Assets and } \\
\text { livelihoods }\end{array}$ \\
\hline $\begin{array}{l}\text { Flood vulnerability perception and } \\
\text { management knowledge }\end{array}$ & $\mathrm{H} 8$ & Human & $\begin{array}{l}\text { Corrective risk } \\
\text { reduction }\end{array}$ & $\begin{array}{l}\text { Assets and } \\
\text { livelihoods }\end{array}$ \\
\hline Understanding of future flood risk & $\mathrm{H} 9$ & Human & $\begin{array}{l}\text { Prospective risk } \\
\text { reduction }\end{array}$ & $\begin{array}{l}\text { Assets and } \\
\text { livelihoods }\end{array}$ \\
\hline Nonerosive flood recovery knowledge & $\mathrm{H} 10$ & Human & Coping & $\begin{array}{l}\text { Assets and } \\
\text { livelihoods }\end{array}$ \\
\hline Flood water and sanitation knowledge & $\mathrm{H} 11$ & Human & Coping & Water \\
\hline Waste management awareness & $\mathrm{H} 12$ & Human & Coping & $\begin{array}{l}\text { Waste } \\
\text { management }\end{array}$ \\
\hline Political awareness & $\mathrm{H} 13$ & Human & $\begin{array}{l}\text { Corrective risk } \\
\text { reduction }\end{array}$ & Governance \\
\hline $\begin{array}{l}\text { Flood provisioning ecosystem services } \\
\text { awareness }\end{array}$ & $\mathrm{H} 14$ & Human & $\begin{array}{l}\text { Prospective risk } \\
\text { reduction }\end{array}$ & $\begin{array}{l}\text { Natural } \\
\text { environment }\end{array}$ \\
\hline Population health status & $\mathrm{H} 15$ & Human & Coping & Life and health \\
\hline Educational attainment & $\mathrm{H} 16$ & Human & $\begin{array}{l}\text { Prospective risk } \\
\text { reduction }\end{array}$ & Education \\
\hline Basin health & N1 & Natural & $\begin{array}{l}\text { Prospective risk } \\
\text { reduction }\end{array}$ & $\begin{array}{l}\text { Natural } \\
\text { environment }\end{array}$ \\
\hline Habitat connectivity & N2 & Natural & $\begin{array}{l}\text { Corrective risk } \\
\text { reduction }\end{array}$ & $\begin{array}{l}\text { Natural } \\
\text { environment }\end{array}$ \\
\hline $\begin{array}{l}\text { Natural habitats maintained for their } \\
\text { flood resilience services }\end{array}$ & N3 & Natural & $\begin{array}{l}\text { Prospective risk } \\
\text { reduction }\end{array}$ & $\begin{array}{l}\text { Natural } \\
\text { environment }\end{array}$ \\
\hline Sustainable use of natural resources & N4 & Natural & $\begin{array}{l}\text { Corrective risk } \\
\text { reduction }\end{array}$ & $\begin{array}{l}\text { Natural } \\
\text { environment }\end{array}$ \\
\hline Conservation management plan & N5 & Natural & $\begin{array}{l}\text { Prospective risk } \\
\text { reduction }\end{array}$ & Governance \\
\hline $\begin{array}{l}\text { National legislation recognizes habitat } \\
\text { restoration }\end{array}$ & N6 & Natural & $\begin{array}{l}\text { Corrective risk } \\
\text { reduction }\end{array}$ & Governance \\
\hline Access to health-care facilities & P1 & Physical & Coping & Life and health \\
\hline Early warning systems & P2 & Physical & $\begin{array}{l}\text { Crisis } \\
\text { preparedness }\end{array}$ & Life and health \\
\hline Measurement and forecasting & P3 & Physical & $\begin{array}{l}\text { Crisis } \\
\text { preparedness }\end{array}$ & Life and health \\
\hline Flood emergency infrastructure & P4 & Physical & $\begin{array}{l}\text { Crisis } \\
\text { preparedness }\end{array}$ & Life and health \\
\hline Access to school facilities & P5 & Physical & $\begin{array}{l}\text { Prospective risk } \\
\text { reduction }\end{array}$ & Education \\
\hline $\begin{array}{l}\text { Individual (household) flood } \\
\text { vulnerability management }\end{array}$ & P6 & Physical & $\begin{array}{l}\text { Corrective risk } \\
\text { reduction }\end{array}$ & $\begin{array}{l}\text { Assets and } \\
\text { livelihoods }\end{array}$ \\
\hline $\begin{array}{l}\text { Communal flood protection } \\
\text { (flood controls) }\end{array}$ & P7 & Physical & $\begin{array}{l}\text { Corrective risk } \\
\text { reduction }\end{array}$ & $\begin{array}{l}\text { Assets and } \\
\text { livelihoods }\end{array}$ \\
\hline
\end{tabular}


Table A1 continued

\begin{tabular}{|c|c|c|c|c|}
\hline Source Name & Code & $5 C$ & DRM Cycle & Theme \\
\hline Basin level flood controls & P8 & Physical & $\begin{array}{l}\text { Prospective risk } \\
\text { reduction }\end{array}$ & $\begin{array}{l}\text { Assets and } \\
\text { livelihoods }\end{array}$ \\
\hline Transportation and community access & P9 & Physical & Coping & $\begin{array}{l}\text { Transport and } \\
\text { communication }\end{array}$ \\
\hline Communication infrastructure & P10 & Physical & Coping & $\begin{array}{l}\text { Transport and } \\
\text { communication }\end{array}$ \\
\hline Lifelines infrastructure & P11 & Physical & $\begin{array}{l}\text { Prospective risk } \\
\text { reduction }\end{array}$ & $\begin{array}{l}\text { Transport and } \\
\text { communication }\end{array}$ \\
\hline Food security & P12 & Physical & Coping & Food \\
\hline Water supply & P13 & Physical & Coping & Water \\
\hline Sanitation facilities & P14 & Physical & Coping & $\begin{array}{l}\text { Waste } \\
\text { management }\end{array}$ \\
\hline Waste collection systems & P15 & Physical & Coping & $\begin{array}{l}\text { Waste } \\
\text { management }\end{array}$ \\
\hline Energy sources & P16 & Physical & Coping & Energy \\
\hline $\begin{array}{l}\text { Social participation in flood } \\
\text { management-related activities }\end{array}$ & S1 & Social & $\begin{array}{l}\text { Crisis } \\
\text { preparedness }\end{array}$ & Life and health \\
\hline $\begin{array}{l}\text { Formal community emergency services } \\
\text { integrate flood advice and management }\end{array}$ & S2 & Social & $\begin{array}{l}\text { Crisis } \\
\text { preparedness }\end{array}$ & Life and health \\
\hline $\begin{array}{l}\text { Access to external, formal flood-related } \\
\text { services }\end{array}$ & S3 & Social & $\begin{array}{l}\text { Crisis } \\
\text { preparedness }\end{array}$ & Life and health \\
\hline $\begin{array}{l}\text { Strategies for the delivery of actionable } \\
\text { information for flood management }\end{array}$ & S4 & Social & $\begin{array}{l}\text { Corrective risk } \\
\text { reduction }\end{array}$ & Life and health \\
\hline Social norms and personal security & S5 & Social & Coping & Life and health \\
\hline Functioning and equitable health system & S6 & Social & $\begin{array}{l}\text { Prospective risk } \\
\text { reduction }\end{array}$ & Life and health \\
\hline $\begin{array}{l}\text { Strategy to maintain or quickly resume } \\
\text { health-care services interrupted by } \\
\text { flooding }\end{array}$ & S7 & Social & $\begin{array}{l}\text { Crisis } \\
\text { preparedness }\end{array}$ & Life and health \\
\hline $\begin{array}{l}\text { Functioning and equitable education } \\
\text { system }\end{array}$ & S8 & Social & $\begin{array}{l}\text { Prospective risk } \\
\text { reduction }\end{array}$ & Education \\
\hline $\begin{array}{l}\text { Strategy to maintain or quickly resume } \\
\text { schooling interrupted by flooding }\end{array}$ & S9 & Social & $\begin{array}{l}\text { Crisis } \\
\text { preparedness }\end{array}$ & Education \\
\hline $\begin{array}{l}\text { Mutual assistance systems and safety } \\
\text { nets }\end{array}$ & $\mathrm{S} 10$ & Social & Coping & Life and health \\
\hline Social norms and security of assets & S11 & Social & Coping & $\begin{array}{l}\text { Assets and } \\
\text { livelihoods }\end{array}$ \\
\hline $\begin{array}{l}\text { Appropriate and equitable access to } \\
\text { mobility }\end{array}$ & S12 & Social & $\begin{array}{l}\text { Prospective risk } \\
\text { reduction }\end{array}$ & $\begin{array}{l}\text { Transport and } \\
\text { communication }\end{array}$ \\
\hline $\begin{array}{l}\text { Strategy to maintain or quickly resume } \\
\text { provision of mobility services in the } \\
\text { event of a flood }\end{array}$ & S13 & Social & $\begin{array}{l}\text { Crisis } \\
\text { preparedness }\end{array}$ & $\begin{array}{l}\text { Transport and } \\
\text { communication }\end{array}$ \\
\hline $\begin{array}{l}\text { Functioning and equitable food supply } \\
\text { systems }\end{array}$ & S14 & Social & $\begin{array}{l}\text { Prospective risk } \\
\text { reduction }\end{array}$ & Food \\
\hline
\end{tabular}


Table A1 continued

\begin{tabular}{|c|c|c|c|c|}
\hline Source Name & Code & $5 C$ & DRM Cycle & Theme \\
\hline $\begin{array}{l}\text { Strategy to maintain or quickly resume } \\
\text { provision of local food supplies in the } \\
\text { event of a flood }\end{array}$ & S15 & Social & $\begin{array}{l}\text { Crisis } \\
\text { preparedness }\end{array}$ & Food \\
\hline $\begin{array}{l}\text { Functioning and equitable water } \\
\text { services }\end{array}$ & S16 & Social & $\begin{array}{l}\text { Prospective risk } \\
\text { reduction }\end{array}$ & Water \\
\hline $\begin{array}{l}\text { Strategy to maintain or quickly resume } \\
\text { provision of local safe water in the event } \\
\text { of a flood }\end{array}$ & S17 & Social & $\begin{array}{l}\text { Crisis } \\
\text { preparedness }\end{array}$ & Water \\
\hline $\begin{array}{l}\text { Functioning and equitable waste } \\
\text { collection and disposal services }\end{array}$ & $\mathrm{S} 18$ & Social & $\begin{array}{l}\text { Prospective risk } \\
\text { reduction }\end{array}$ & $\begin{array}{l}\text { Waste } \\
\text { management }\end{array}$ \\
\hline $\begin{array}{l}\text { Strategy to maintain or quickly resume } \\
\text { local waste collection and disposal } \\
\text { services in the event of a flood }\end{array}$ & S19 & Social & $\begin{array}{l}\text { Crisis } \\
\text { preparedness }\end{array}$ & $\begin{array}{l}\text { Waste } \\
\text { management }\end{array}$ \\
\hline $\begin{array}{l}\text { Appropriate and equitable access to } \\
\text { energy }\end{array}$ & S20 & Social & $\begin{array}{l}\text { Prospective risk } \\
\text { reduction }\end{array}$ & Energy \\
\hline $\begin{array}{l}\text { Strategy to maintain or quickly resume } \\
\text { local energy supply in the event of a } \\
\text { flood }\end{array}$ & S21 & Social & $\begin{array}{l}\text { Crisis } \\
\text { preparedness }\end{array}$ & Energy \\
\hline $\begin{array}{l}\text { Community representative bodies and } \\
\text { structures for flood management } \\
\text { coordination }\end{array}$ & S22 & Social & $\begin{array}{l}\text { Corrective risk } \\
\text { reduction }\end{array}$ & Governance \\
\hline Social inclusiveness & S23 & Social & $\begin{array}{l}\text { Corrective risk } \\
\text { reduction }\end{array}$ & Governance \\
\hline Social leadership & S24 & Social & $\begin{array}{l}\text { Prospective risk } \\
\text { reduction }\end{array}$ & Governance \\
\hline $\begin{array}{l}\text { Culture for community information } \\
\text { sharing }\end{array}$ & S25 & Social & $\begin{array}{l}\text { Corrective risk } \\
\text { reduction }\end{array}$ & Governance \\
\hline Village or district flood plan & S26 & Social & $\begin{array}{l}\text { Prospective risk } \\
\text { reduction }\end{array}$ & Governance \\
\hline $\begin{array}{l}\text { Coordination mechanism across } \\
\text { communities }\end{array}$ & S27 & Social & $\begin{array}{l}\text { Crisis } \\
\text { preparedness }\end{array}$ & Governance \\
\hline $\begin{array}{l}\text { Watershed and/or basin scale } \\
\text { management plan and structure }\end{array}$ & S28 & Social & $\begin{array}{l}\text { Corrective risk } \\
\text { reduction }\end{array}$ & Governance \\
\hline $\begin{array}{l}\text { National policy and plan for forecasting } \\
\text { ability }\end{array}$ & S29 & Social & $\begin{array}{l}\text { Crisis } \\
\text { preparedness }\end{array}$ & Governance \\
\hline $\begin{array}{l}\text { Government policies and planning and } \\
\text { mainstreaming of flood risk }\end{array}$ & $\mathrm{S} 30$ & Social & $\begin{array}{l}\text { Prospective risk } \\
\text { reduction }\end{array}$ & Governance \\
\hline Flood regulation and local enforcement & S31 & Social & $\begin{array}{l}\text { Prospective risk } \\
\text { reduction }\end{array}$ & Governance \\
\hline $\begin{array}{l}\text { National environment conservation } \\
\text { legislation }\end{array}$ & S32 & Social & $\begin{array}{l}\text { Prospective risk } \\
\text { reduction }\end{array}$ & $\begin{array}{l}\text { Natural } \\
\text { environment }\end{array}$ \\
\hline $\begin{array}{l}\text { Community plan for the sustainable } \\
\text { management of natural resources and } \\
\text { preservation of ecosystem services }\end{array}$ & S33 & Social & $\begin{array}{l}\text { Prospective risk } \\
\text { reduction }\end{array}$ & $\begin{array}{l}\text { Natural } \\
\text { environment }\end{array}$ \\
\hline
\end{tabular}

$5 C$ = five capitals, $D R M=$ disaster risk management.

Source: Authors' own. 


\section{Appendix 2: Descriptive Statistics of the Theme Lens}

In general, we assume nonparametric variables because of nonnormality (see Table A2.1 with Shapiro-Wilk and Kolmogrov-Smirnov tests) and the nonhomogeneity of variance (see Table A2.2 with Levene test).

Table A2.1: Tests of Normality with Kolmogorov-Smirnov and Shapiro-Wilk

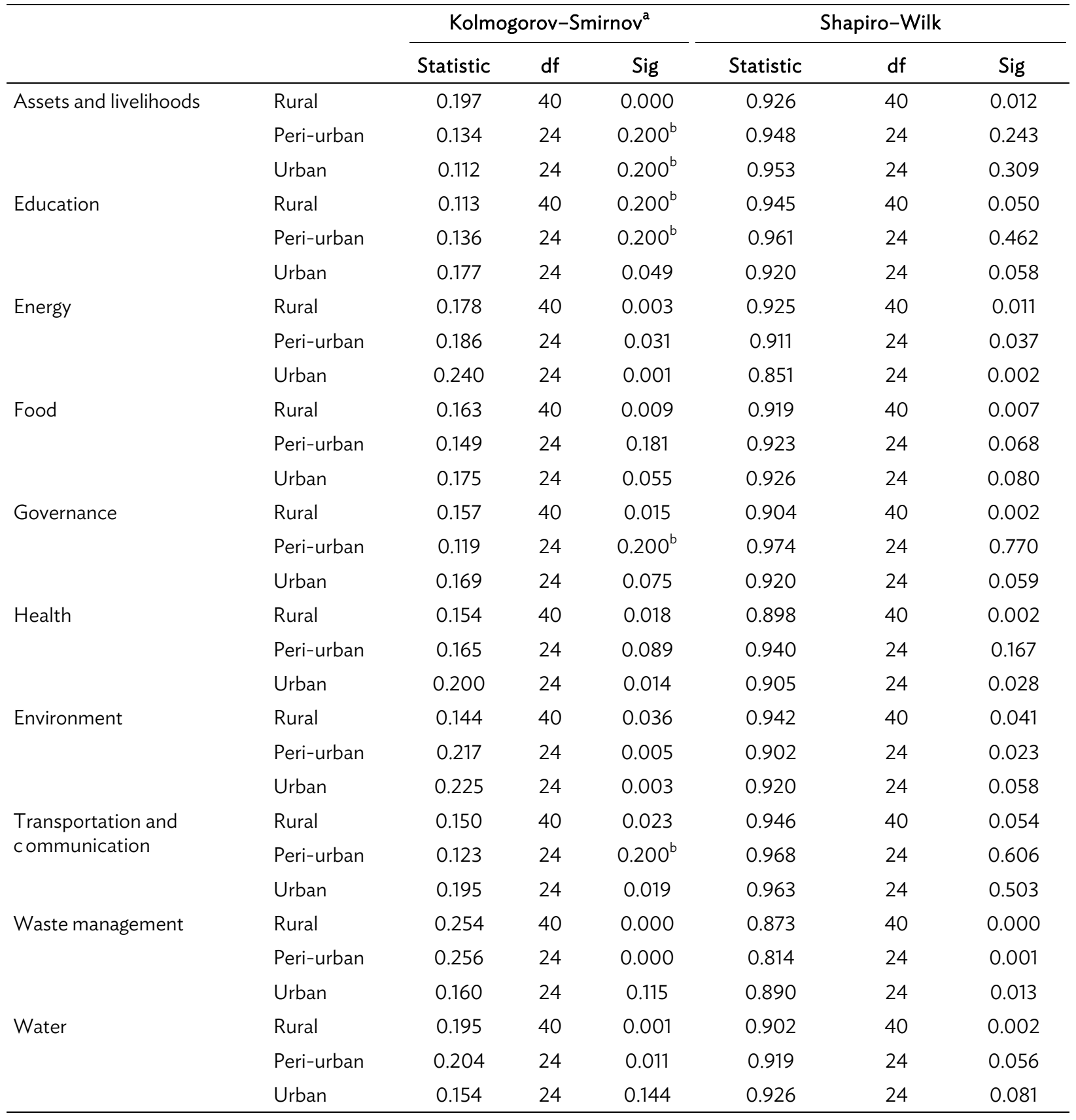

$\mathrm{df}=$ degrees of freedom, sig = significance.

${ }^{a}$ Lilliefors significance correction.

${ }^{b}$ This is a lower bound of the true significance.

Source: Authors' own. 
Table A2.2: Test of Homogeneity of Variances

\begin{tabular}{lcccc}
\hline Levene Statistic & & df1 & df2 & Sig \\
\hline Assets and livelihoods & 3.520 & 2 & 85 & 0.034 \\
Education & 0.478 & 2 & 85 & 0.621 \\
Energy & 6.302 & 2 & 85 & 0.003 \\
Food & 0.469 & 2 & 85 & 0.627 \\
Governance & 10.786 & 2 & 85 & 0.000 \\
Health & 16.097 & 2 & 85 & 0.000 \\
Environment & 16.892 & 2 & 85 & 0.000 \\
Transportation and communication & 1.887 & 2 & 85 & 0.158 \\
Waste management & 0.045 & 2 & 85 & 0.956 \\
Water & 2.640 & 2 & 85 & 0.077 \\
\hline
\end{tabular}

$\mathrm{df} 1=$ degrees of freedom $1, \mathrm{df} 2=$ degrees of freedom 2, sig $=$ significance .

Source: Authors' own.

\section{Nonparametric Tests}

Table A2.3: Hypothesis Test Summary of Independent Samples, Kruskal-Wallis Test

\begin{tabular}{|c|c|c|c|c|c|}
\hline Null Hypothesis & Test & Chi-square df & Sig & Decision & Null Hypothesis \\
\hline $\begin{array}{l}\text { The distribution } \\
\text { of theme_asses_- } \\
\text { livelih is the same } \\
\text { across categories } \\
\text { of rural_urban. }\end{array}$ & $\begin{array}{l}\text { Independent } \\
\text { samples Kruskal- } \\
\text { Wallis test }\end{array}$ & 13.593 & 2 & 0.001 & $\begin{array}{l}\text { Reject the null } \\
\text { hypothesis }\end{array}$ \\
\hline $\begin{array}{l}\text { The distribution of } \\
\text { theme_educ is the } \\
\text { same across } \\
\text { categories of } \\
\text { rural_urban. }\end{array}$ & $\begin{array}{l}\text { Independent } \\
\text { samples Kruskal- } \\
\text { Wallis test }\end{array}$ & 22.790 & 2 & 0.000 & $\begin{array}{l}\text { Reject the null } \\
\text { hypothesis }\end{array}$ \\
\hline $\begin{array}{l}\text { The distribution of } \\
\text { theme_energ is the } \\
\text { same across } \\
\text { categories of } \\
\text { rural_urban. }\end{array}$ & $\begin{array}{l}\text { Independent } \\
\text { samples Kruskal- } \\
\text { Wallis test }\end{array}$ & 15.727 & 2 & 0.000 & $\begin{array}{l}\text { Reject the null } \\
\text { hypothesis }\end{array}$ \\
\hline $\begin{array}{l}\text { The distribution of } \\
\text { theme_food is the } \\
\text { same across } \\
\text { categories of } \\
\text { rural_urban. }\end{array}$ & $\begin{array}{l}\text { Independent } \\
\text { samples Kruskal- } \\
\text { Wallis test }\end{array}$ & 38.951 & 2 & 0.000 & $\begin{array}{l}\text { Reject the null } \\
\text { hypothesis }\end{array}$ \\
\hline $\begin{array}{l}\text { The distribution of } \\
\text { theme_govern is } \\
\text { the same across } \\
\text { categories of } \\
\text { rural_urban. }\end{array}$ & $\begin{array}{l}\text { Independent } \\
\text { samples Kruskal- } \\
\text { Wallis test }\end{array}$ & 1.388 & 2 & 0.500 & $\begin{array}{l}\text { Retain the null } \\
\text { hypothesis }\end{array}$ \\
\hline
\end{tabular}


Appendix | 31

Table A2.3 continued

\begin{tabular}{|c|c|c|c|c|c|}
\hline Null Hypothesis & Test & Chi-square df & Sig & Decision & Null Hypothesis \\
\hline $\begin{array}{l}\text { The distribution of } \\
\text { theme_health is } \\
\text { the same across } \\
\text { categories of } \\
\text { rural_urban. }\end{array}$ & $\begin{array}{l}\text { Independent } \\
\text { samples Kruskal- } \\
\text { Wallis test }\end{array}$ & 3.001 & 2 & 0.223 & $\begin{array}{l}\text { Retain the null } \\
\text { hypothesis }\end{array}$ \\
\hline $\begin{array}{l}\text { The distribution of } \\
\text { theme_environ is } \\
\text { the same across } \\
\text { categories of } \\
\text { rural_urban. }\end{array}$ & $\begin{array}{l}\text { Independent } \\
\text { samples Kruskal- } \\
\text { Wallis test }\end{array}$ & 3.093 & 2 & 0.213 & $\begin{array}{l}\text { Retain the null } \\
\text { hypothesis }\end{array}$ \\
\hline $\begin{array}{l}\text { The distribution of } \\
\text { theme_transp_co } \\
m \text { is the same } \\
\text { across categories of } \\
\text { rural_urban. }\end{array}$ & $\begin{array}{l}\text { Independent } \\
\text { samples Kruskal- } \\
\text { Wallis test }\end{array}$ & 13.775 & 2 & 0.001 & $\begin{array}{l}\text { Reject the null } \\
\text { hypothesis }\end{array}$ \\
\hline $\begin{array}{l}\text { The distribution of } \\
\text { theme_waste is the } \\
\text { same across } \\
\text { categories of } \\
\text { rural_urban. }\end{array}$ & $\begin{array}{l}\text { Independent } \\
\text { samples Kruskal- } \\
\text { Wallis test }\end{array}$ & 23.543 & 2 & 0.000 & $\begin{array}{l}\text { Reject the null } \\
\text { hypothesis }\end{array}$ \\
\hline $\begin{array}{l}\text { The distribution of } \\
\text { theme_water is the } \\
\text { same across } \\
\text { categories of } \\
\text { rural_urban. }\end{array}$ & $\begin{array}{l}\text { Independent } \\
\text { samples Kruskal- } \\
\text { Wallis test }\end{array}$ & 24.190 & 2 & 0.000 & $\begin{array}{l}\text { Reject the null } \\
\text { hypothesis }\end{array}$ \\
\hline
\end{tabular}

$\mathrm{df}=$ degrees of freedom, sig = significance.

Notes: Asymptotic significances are displayed. The significance level is 0.05 .

Source: Authors' own.

Table A2.4: Descriptive Statistics of Theme Lens for Kruskal-Wallis Test

\begin{tabular}{llll}
\hline & & $\mathrm{N}$ & Rank \\
\hline Assets and livelihoods & Rural & 40 & 36.23 \\
& Peri-urban & 24 & 42.46 \\
& Urban & 24 & 60.33 \\
& Total & 88 & \\
Education & Rural & 40 & 30.79 \\
& Peri-urban & 24 & 51.31 \\
& Urban & 24 & 60.54 \\
Energy & Total & 88 & \\
& Rural & 40 & 35.54 \\
& Peri-urban & 24 & 42.60 \\
& Urban & 24 & 61.33 \\
\hline & Total & 88 & \\
\hline
\end{tabular}


Table A2.4 continued

\begin{tabular}{|c|c|c|c|}
\hline & & $\mathrm{N}$ & Rank \\
\hline \multirow[t]{4}{*}{ Food } & Rural & 40 & 27.36 \\
\hline & Peri-urban & 24 & 50.48 \\
\hline & Urban & 24 & 67.08 \\
\hline & Total & 88 & \\
\hline \multirow[t]{4}{*}{ Governance } & Rural & 40 & 44.10 \\
\hline & Peri-urban & 24 & 49.15 \\
\hline & Urban & 24 & 40.52 \\
\hline & Total & 88 & \\
\hline \multirow[t]{4}{*}{ Health } & Rural & 40 & 39.78 \\
\hline & Peri-urban & 24 & 45.85 \\
\hline & Urban & 24 & 51.02 \\
\hline & Total & 88 & \\
\hline \multirow[t]{4}{*}{ Environment } & Rural & 40 & 47.70 \\
\hline & Peri-urban & 24 & 46.94 \\
\hline & Urban & 24 & 36.73 \\
\hline & Total & 88 & \\
\hline \multirow[t]{4}{*}{ Transportation and communication } & Rural & 40 & 35.40 \\
\hline & Peri-urban & 24 & 44.40 \\
\hline & Urban & 24 & 59.77 \\
\hline & Total & 88 & \\
\hline \multirow[t]{4}{*}{ Waste management } & Rural & 40 & 35.76 \\
\hline & Peri-urban & 24 & 37.75 \\
\hline & Urban & 24 & 65.81 \\
\hline & Total & 88 & \\
\hline \multirow[t]{4}{*}{ Water } & Rural & 40 & 36.94 \\
\hline & Peri-urban & 24 & 35.44 \\
\hline & Urban & 24 & 66.17 \\
\hline & Total & 88 & \\
\hline
\end{tabular}

$N=$ sample size.

Source: Authors' own

Table A2.5: Assets and Livelihoods across Settlement Types with Independent Samples, Kruskal-Wallis Test Summary

\begin{tabular}{|l|c|}
\hline Total sample size & 88 \\
\hline Test statistic & $13.593^{\mathrm{a}}$ \\
\hline Degrees of freedom & 2 \\
\hline Asymptotic significance (2-sided test) & 0.001 \\
\hline
\end{tabular}

${ }^{a}$ The test statistic is adjusted for ties. Source: Authors' own. 
Table A2.6: Post-Hoc Test for Assets and Livelihoods Pairwise Comparisons of Settlement Types with Independent Samples, Kruskal-Wallis Test

\begin{tabular}{lccccc}
\hline Sample 1-Sample 2 & Test Statistic & Std Error & Std Test Statistic & Sig & Adj Sig $^{\mathrm{a}}$ \\
\hline Rural-Peri-urban & -6.233 & 6.590 & -0.946 & 0.344 & 1.000 \\
Rural-Urban & -24.108 & 6.590 & -3.658 & 0.000 & 0.001 \\
Peri-urban-Urban & -17.875 & 7.368 & -2.426 & 0.015 & 0.046 \\
\hline
\end{tabular}

adj sig = adjusted significance, sig = significance, std = standard .

a Significance values have been adjusted by the Bonferroni correction for multiple tests.

Note: Each row tests the null hypothesis that the sample 1 and sample 2 distributions are the same.

Source: Authors' own.

Table A2.7: Education across Settlement Types with Independent Samples, Kruskal-Wallis Test Summary

\begin{tabular}{|l|c|}
\hline Total sample size & 88 \\
\hline Test statistic & $22.790^{\mathrm{a}}$ \\
\hline Degrees of freedom & 2 \\
\hline Asymptotic significance (2-sided test) & 0.000 \\
\hline
\end{tabular}

${ }^{a}$ The test statistic is adjusted for ties.

Source: Authors' own.

\section{Table A2.8: Post-Hoc Test for Education Pairwise Comparisons of Settlement Types with Independent Samples, Kruskal-Wallis Test}

\begin{tabular}{lccccc}
\hline Sample 1-Sample 2 & Test Statistic & Std Error & Std Test Statistic & Sig & Adj Sig $^{2}$ \\
\hline Rural-Peri-urban & -20.525 & 6.582 & -3.118 & 0.002 & 0.005 \\
Rural-Urban & -29.754 & 6.582 & -4.520 & 0.000 & 0.000 \\
Peri-urban-Urban & -9.229 & 7.359 & -1.254 & 0.210 & 0.629 \\
\hline
\end{tabular}

adj sig = adjusted significance, sig = significance, std $=$ standard .

${ }^{a}$ Significance values have been adjusted by the Bonferroni correction for multiple tests.

Note: Each row tests the null hypothesis that the sample 1 and sample 2 distributions are the same.

Source: Authors' own.

Table A2.9: Energy across Settlement Types with Independent Samples, Kruskal-Wallis Test Summary

\begin{tabular}{|l|c|}
\hline Total sample size & 88 \\
\hline Test statistic & $15.727^{\mathrm{a}}$ \\
\hline Degrees of freedom & 2 \\
\hline Asymptotic significance (2-sided test) & 0.000 \\
\hline
\end{tabular}

${ }^{a}$ The test statistic is adjusted for ties. Source: Authors' own. 
Table A2.10: Post-Hoc Test for Energy Pairwise Comparisons of Settlement Types with Independent Samples, Kruskal-Wallis Test

\begin{tabular}{lccccc}
\hline Sample 1-Sample 2 & Test Statistic & Std Error & Std Test Statistic & Sig & Adj Sig $^{\mathrm{a}}$ \\
\hline Rural-Peri-urban & -7.067 & 6.543 & -1.080 & 0.280 & 0.840 \\
Rural-Urban & -25.796 & 6.543 & -3.942 & 0.000 & 0.000 \\
Peri-urban-Urban & -18.729 & 7.315 & -2.560 & 0.010 & 0.031 \\
\hline
\end{tabular}

adj sig = adjusted significance, sig = significance, std = standard .

a Significance values have been adjusted by the Bonferroni correction for multiple tests.

Note: Each row tests the null hypothesis that the sample 1 and sample 2 distributions are the same.

Source: Authors' own.

Table A2.11: Food across Settlement Types with Independent Samples, Kruskal-Wallis Test Summary

\begin{tabular}{|l|c|}
\hline Total sample size & 88 \\
\hline Test statistic & $38.951^{\mathrm{a}}$ \\
\hline Degrees of freedom & 2 \\
\hline Asymptotic significance (2-sided test) & 0.000 \\
\hline
\end{tabular}

${ }^{a}$ The test statistic is adjusted for ties.

Source: Authors' own.

Table A2.12: Post-Hoc Test for Food Pairwise Comparisons of Settlement Types with Independent Samples, Kruskal-Wallis Test

\begin{tabular}{lccccc}
\hline Sample 1-Sample 2 & Test Statistic & Std Error & Std Test Statistic & Sig & Adj Sig $^{\mathrm{a}}$ \\
\hline Rural-Peri-urban & -23.117 & 6.521 & -3.545 & 0.000 & 0.001 \\
Rural-Urban & -39.721 & 6.521 & -6.091 & 0.000 & 0.000 \\
Peri-urban-Urban & -16.604 & 7.291 & -2.277 & 0.023 & 0.068 \\
\hline
\end{tabular}

adj sig = adjusted significance, sig = significance, std $=$ standard .

a Significance values have been adjusted by the Bonferroni correction for multiple tests.

Note: Each row tests the null hypothesis that the sample 1 and sample 2 distributions are the same.

Source: Authors' own.

Table A2.13: Governance across Settlement Types with Independent Samples, Kruskal-Wallis Test Summary

\begin{tabular}{|l|c|}
\hline Total sample size & 88 \\
\hline Test statistic & $1.388^{\mathrm{a}, \mathrm{b}}$ \\
\hline Degrees of freedom & 2 \\
\hline Asymptotic significance (2-sided test) & 0.500 \\
\hline
\end{tabular}

${ }^{a}$ The test statistic is adjusted for ties.

${ }^{b}$ Multiple comparisons are not performed because the overall test does not show significant differences across samples.

Source: Authors' own. 
Table A2.14: Health across Settlement Types with Independent Samples, Kruskal-Wallis Test Summary

\begin{tabular}{|l|c|}
\hline Total sample size & 88 \\
\hline Test statistic & $3.001^{\mathrm{a}, \mathrm{b}}$ \\
\hline Degrees of freedom & 2 \\
\hline Asymptotic significance (2-sided test) & 0.223 \\
\hline
\end{tabular}

a The test statistic is adjusted for ties.

${ }^{b}$ Multiple comparisons are not performed because the overall test does not show significant differences across samples.

Source: Authors' own.

Table A2.15: Environment across Settlement Types with Independent Samples, Kruskal-Wallis Test Summary

\begin{tabular}{|l|c|}
\hline Total sample size & 88 \\
\hline Test statistic & $3.093^{\mathrm{a}, \mathrm{b}}$ \\
\hline Degrees of freedom & 2 \\
\hline Asymptotic significance (2-sided test) & 0.213 \\
\hline
\end{tabular}

${ }^{a}$ The test statistic is adjusted for ties.

${ }^{\mathrm{b}}$ Multiple comparisons are not performed because the overall test does not show significant differences across samples.

Source: Authors' own.

Table A2.16: Transportation and Communication across Settlement Types with Independent Samples, Kruskal-Wallis Test Summary

\begin{tabular}{|l|c|}
\hline Total sample size & 88 \\
\hline Test statistic & $13.775^{\mathrm{a}}$ \\
\hline Degrees of freedom & 2 \\
\hline Asymptotic significance (2-sided test) & 0.001 \\
\hline
\end{tabular}

${ }^{a}$ The test statistic is adjusted for ties.

Source: Authors' own.

\section{Table A2.17: Post-Hoc Test for Transportation and Communication Pairwise Comparisons of} Settlement Types with Independent Samples, Kruskal-Wallis Test

\begin{tabular}{lccccc}
\hline Sample 1-Sample 2 & Test Statistic & Std Error & Std Test Statistic & Sig & Adj Sig $^{\mathrm{a}}$ \\
\hline Rural-Peri-urban & -8.996 & 6.566 & -1.370 & 0.171 & 0.512 \\
Rural-urban & -24.371 & 6.566 & -3.711 & 0.000 & 0.001 \\
Peri-urban-Urban & -15.375 & 7.342 & -2.094 & 0.036 & 0.109 \\
\hline
\end{tabular}

adj sig = adjusted significance, $\operatorname{sig}=$ significance, std $=$ standard .

${ }^{a}$ Significance values have been adjusted by the Bonferroni correction for multiple tests.

Notes: Each row tests the null hypothesis that the sample 1 and sample 2 distributions are the same. Asymptotic significances (2-sided tests) are displayed. The significance level is 0.05 .

Source: Authors' own. 
Table A2.18: Waste across Settlement Types with Independent Samples, Kruskal-Wallis Test Summary

\begin{tabular}{|l|c|}
\hline Total sample size & 88 \\
\hline Test statistic & $23.543^{\mathrm{a}}$ \\
\hline Degrees of freedom & 2 \\
\hline Asymptotic significance (2-sided test) & 0.000 \\
\hline
\end{tabular}

${ }^{a}$ The test statistic is adjusted for ties. Source: Authors' own.

\section{Table A2.19: Post-Hoc Test for Waste Pairwise Comparisons of Settlement Types with Independent Samples, Kruskal-Wallis Test}

\begin{tabular}{lccccc}
\hline Sample 1-Sample 2 & Test Statistic & Std Error & Std Test Statistic & Sig & Adj Sig $^{\mathrm{a}}$ \\
\hline Rural-Peri-urban & -1.988 & 6.528 & -0.304 & 0.761 & 1.000 \\
Rural-Urban & -30.050 & 6.528 & -4.603 & 0.000 & 0.000 \\
Peri-urban-Urban & -28.063 & 7.298 & -3.845 & 0.000 & 0.000 \\
\hline
\end{tabular}

adj sig = adjusted significance, sig = significance, std = standard

${ }^{a}$ Significance values have been adjusted by the Bonferroni correction for multiple tests.

Note: Each row tests the null hypothesis that the sample 1 and sample 2 distributions are the same.

Source: Authors' own.

Table A2.20: Water across Settlement Types with Independent Samples, Kruskal-Wallis Test Summary

\begin{tabular}{|l|c|}
\hline Total sample size & 88 \\
\hline Test statistic & $24.190^{\mathrm{a}}$ \\
\hline Degrees of freedom & 2 \\
\hline Asymptotic significance (2-sided test) & 0.000 \\
\hline
\end{tabular}

${ }^{a}$ The test statistic is adjusted for ties.

Source: Authors' own.

Table A2.21: Post-Hoc Test for Water Pairwise Comparisons of Settlement Types with Independent Samples, Kruskal-Wallis Test

\begin{tabular}{lccccc}
\hline Sample 1-Sample 2 & Test Statistic & Std Error & Std Test Statistic & Sig & Adj Sig $^{a}$ \\
\hline Peri-urban-Rural & 1.500 & 6.541 & 0.229 & 0.819 & 1.000 \\
Peri-urban-Urban & -30.729 & 7.313 & -4.202 & 0.000 & 0.000 \\
Rural-Urban & -29.229 & 6.541 & -4.468 & 0.000 & 0.000 \\
\hline
\end{tabular}

adj sig = adjusted significance, sig = significance, std = standard.

${ }^{a}$ Significance values have been adjusted by the Bonferroni correction for multiple tests.

Notes: Each row tests the null hypothesis that the sample 1 and sample 2 distributions are the same.

Source: Authors' own. 


\section{Appendix 3: Descriptive Statistics of Disaster Risk Management Cycle Properties}

In general, we assume nonparametric variables because of nonnormality (see Table A3.1 with Shapiro-Wilk and Kolmogrov-Smirnov test) and the nonhomogeneity of variance (see Table A3.2 with Levene test).

Table A3.1: Tests of Normality with Kolmogorov-Smirnov and Shapiro-Wilk

\begin{tabular}{lccccccc}
\hline & \multicolumn{3}{c}{ Kolmogorov-Smirnov $^{\mathrm{a}}$} & & \multicolumn{3}{c}{ Shapiro-Wilk } \\
\cline { 2 - 4 } \cline { 7 - 8 } & Statistic & $\mathrm{df}$ & Sig & & Statistic & $\mathrm{df}$ & Sig \\
\hline DRM coping & 0.080 & 88 & $0.200^{\mathrm{b}}$ & & 0.970 & 88 & 0.040 \\
$\begin{array}{l}\text { DRM corrective } \\
\text { risk reduction }\end{array}$ & 0.089 & 88 & 0.085 & & 0.961 & 88 & 0.009 \\
$\begin{array}{l}\text { DRM crisis } \\
\text { preparedness }\end{array}$ & 0.134 & 88 & 0.001 & & 0.939 & 88 & 0.000 \\
$\begin{array}{l}\text { DRM } \\
\text { prospective risk } \\
\text { reduction }\end{array}$ & 0.094 & 88 & 0.054 & 0.954 & 88 & 0.003 \\
\hline
\end{tabular}

$\mathrm{df}=$ degrees of freedom, $\mathrm{DRM}=$ disaster risk management, sig = significance.

a Lilliefors significance correction.

${ }^{b}$ This is a lower bound of the true significance.

Source: Authors' own.

Peri-urban is the only settlement type that is in three out of four DRM cycle properties normally distributed. Rural is only normally distributed in coping strategies and urban is not normally distributed.

Table A3.2: Test of Homogeneity of Variances

\begin{tabular}{lcccc}
\hline Levene Statistic & & $\mathrm{df1}$ & $\mathrm{df2}$ & Sig \\
\hline DRM coping & 0.924 & 2 & 85 & 0.401 \\
DRM corrective risk & 15.134 & 2 & 85 & 0.000 \\
DRM crisis & 10.330 & 2 & 85 & 0.000 \\
DRM prospective risk & 5.436 & 2 & 85 & 0.006 \\
\hline
\end{tabular}

$\mathrm{df1}=$ degrees of freedom 1, df2 = degrees of freedom 2, DRM = disaster risk management, sig = significance. Source: Authors' own. 
Nonparametric Tests

Table A3.3: Hypothesis Test Summary of Independent Samples, Kruskal-Wallis Test

\begin{tabular}{|c|c|c|c|c|c|}
\hline Null Hypothesis & Test & Chi-square & $\mathrm{df}$ & Sig & Decision \\
\hline $\begin{array}{l}\text { The distribution of prospective risk } \\
\text { reduction is the same across } \\
\text { categories of settlement types. }\end{array}$ & $\begin{array}{l}\text { Independent samples } \\
\text { Kruskal-Wallis test }\end{array}$ & 11.742 & 2 & 0.003 & $\begin{array}{l}\text { Reject the null } \\
\text { hypothesis }\end{array}$ \\
\hline $\begin{array}{l}\text { The distribution of corrective risk } \\
\text { reduction is the same across } \\
\text { categories settlement types. }\end{array}$ & $\begin{array}{l}\text { Independent samples } \\
\text { Kruskal-Wallis test }\end{array}$ & 0.530 & 2 & 0.767 & $\begin{array}{l}\text { Retain the null } \\
\text { hypothesis }\end{array}$ \\
\hline $\begin{array}{l}\text { The distribution of crisis } \\
\text { preparedness is the same across } \\
\text { categories of settlement types. }\end{array}$ & $\begin{array}{l}\text { Independent samples } \\
\text { Kruskal-Wallis test }\end{array}$ & 1.280 & 2 & 0.527 & $\begin{array}{l}\text { Retain the null } \\
\text { hypothesis }\end{array}$ \\
\hline $\begin{array}{l}\text { The distribution of coping strategies } \\
\text { is the same across categories of } \\
\text { settlement types. }\end{array}$ & $\begin{array}{l}\text { Independent samples } \\
\text { Kruskal-Wallis test }\end{array}$ & 32.079 & 2 & 0.000 & $\begin{array}{l}\text { Retain the null } \\
\text { hypothesis }\end{array}$ \\
\hline
\end{tabular}

$\mathrm{df}=$ degrees of freedom, $\mathrm{sig}=$ significance.

Notes: Asymptotic significances are displayed. The significance level is 0.05 .

Source: Authors' own.

Table A3.4: Descriptive Statistics of Disaster Risk Management Cycle Properties for Kruskal-Wallis Test

\begin{tabular}{lllc}
\hline & & N & Mean Rank \\
\hline DRM coping & Rural & 40 & 30.65 \\
& Peri-urban & 24 & 44.08 \\
& Urban & 24 & 68.00 \\
DRM corrective risk reduction & Total & 88 & \\
& Rural & 40 & 45.94 \\
& Peri-urban & 24 & 45.31 \\
& Urban & 24 & 41.29 \\
DRM crisis preparedness & Total & 88 & \\
& Rural & 40 & 41.55 \\
& Peri-urban & 24 & 48.98 \\
& Urban & 24 & 44.94 \\
& Total & 88 & \\
& Rural & 40 & 35.73 \\
& Peri-urban & 24 & 45.33 \\
& Urban & 24 & 58.29 \\
& Total & 88 & \\
\hline
\end{tabular}

DRM = disaster risk management, $\mathrm{N}=$ sample size.

Source: Authors' own. 
Table A3.5: Prospective Risk Reduction across Settlement Types with Independent Samples, Kruskal-Wallis Test Summary

\begin{tabular}{|l|c|}
\hline Total sample size & 88 \\
\hline Test statistic & $11.742^{\mathrm{a}}$ \\
\hline Degrees of freedom & 2 \\
\hline Asymptotic significance (2-sided test) & 0.003 \\
\hline
\end{tabular}

${ }^{a}$ The test statistic is adjusted for ties.

Source: Authors' own.

Table A3.6: Post-Hoc Test for Prospective Risk Reduction: Pairwise Comparisons of Settlement Types with Independent Samples, Kruskal-Wallis Test

\begin{tabular}{lccccc}
\hline Sample 1-Sample 2 & Test Statistic & Std Error & Test Statistic & Sig & Adj Sig $^{\mathrm{a}}$ \\
\hline Rural-Peri-urban & -9.608 & 6.595 & -1.457 & 0.145 & 0.435 \\
Rural-Urban & -22.567 & 6.595 & -3.422 & 0.001 & 0.002 \\
Peri-urban-Urban & -12.958 & 7.374 & -1.757 & 0.079 & 0.237 \\
\hline
\end{tabular}

adj sig = adjusted significance, sig = significance, std $=$ standard .

a Significance values have been adjusted by the Bonferroni correction for multiple tests.

Notes: Each row tests the null hypothesis that the sample 1 and sample 2 distributions are the same. Asymptotic significances (2-sided tests) are displayed. The significance level is 0.05 .

Source: Authors' own.

\section{Table A3.7: Corrective Risk Reduction across Settlement Types with Independent Samples, Kruskal-Wallis Test Summary}

\begin{tabular}{|l|c|}
\hline Total sample size & 88 \\
\hline Test statistic & $530.000^{\mathrm{a}, \mathrm{b}}$ \\
\hline Degrees of freedom & 2 \\
\hline Asymptotic significance (2-sided test) & 0.767 \\
\hline
\end{tabular}

${ }^{a}$ The test statistic is adjusted for ties.

${ }^{\mathrm{b}}$ Multiple comparisons are not performed because the overall test does not show significant differences across samples.

Source: Authors' own.

\section{Table A3.8: Crisis Preparedness across Settlement Types with Independent Samples, Kruskal-Wallis Test Summary}

\begin{tabular}{|l|c|}
\hline Total sample size & 88 \\
\hline Test statistic & $1.280^{\mathrm{a}, \mathrm{b}}$ \\
\hline Degrees of freedom & 2 \\
\hline Asymptotic significance (2-sided test) & 0.527 \\
\hline
\end{tabular}

${ }^{a}$ The test statistic is adjusted for ties.

${ }^{b}$ Multiple comparisons are not performed because the overall test does not show significant differences across samples.

Source: Authors' own. 
Table A3.9: Coping across Settlement Types with Independent Samples, Kruskal-Wallis Test Summary

\begin{tabular}{|l|c|}
\hline Total sample size & 88 \\
\hline Test statistic & $32.079^{\mathrm{a}}$ \\
\hline Degrees of freedom & 2 \\
\hline Asymptotic significance (2-sided test) & 0.000 \\
\hline
\end{tabular}

${ }^{a}$ The test statistic is adjusted for ties. Source: Authors' own.

Table A3.10: Post-Hoc Test for Coping Strategies: Pairwise Comparisons of Settlement Types with Independent Samples, Kruskal-Wallis Test

\begin{tabular}{|c|c|c|c|c|c|}
\hline Sample 1-Sample 2 & Test Statistic & Std Error & Test Statistic & Sig & Adj Sig ${ }^{a}$ \\
\hline Rural-Peri-urban & -13.433 & 6.595 & -2.037 & 0.042 & 0.125 \\
\hline Rural-Urban & -37.350 & 6.595 & -5.663 & 0.000 & 0.000 \\
\hline Peri-urban-Urban & -23.917 & 7.374 & -3.243 & 0.001 & 0.004 \\
\hline
\end{tabular}

adj sig = adjusted significance, sig = significance, std = standard .

${ }^{a}$ Significance values have been adjusted by the Bonferroni correction for multiple tests.

Notes: Each row tests the null hypothesis that the sample 1 and sample 2 distributions are the same. Asymptotic significances (2-sided tests) are displayed. The significance level is 0.05 .

Source: Authors' own. 


\section{REFERENCES}

Adger, W. Neil, Terry P. Hughes, Carl Folke, Stephen R. Carpenter, and Johan Rockström. 2005. "Social-Ecological Resilience to Coastal Disasters." Science 309 (5737): 1036-39. https://doi.org/10.1126/science.1112122.

Asadzadeh, A., T. Kötter, P. Salehi, and J. Birkmann. 2017. "Operationalizing a Concept: The Systematic Review of Composite Indicator Building for Measuring Community Disaster Resilience." International Journal of Disaster Risk Reduction 25: 147-62. https://doi.org/10.1016/j.ijdrr.2017.09.015.

Ashley, Richard, Dennis Parker, Louise Hurley, and Cashman Adrian. 2008. Flooding: Engineering Resilience. Flood Hazard Research Centre. http://redac.eng.usm.my/EAD/EAD511/ Ashley2008.pdf.

Asian Development Bank (ADB). 2013. Investing in Resilience: Ensuring a Disaster-Resistant Future. Manila. https://www.adb.org/sites/default/files/publication/30119/investing-resilience.pdf

Backhaus, Klaus, Bernd Erichson, Wulff Plinke, and Rolf Weiber. 2016. Multivariate Analysemethoden: Eine Anwendungsorientierte Einführung. Vol. 14. Springer-Verlag Berlin Heidelberg. https://doi.org/10.1007/978-3-662-46076-4.

Barrett, Christopher B, Mark A Constas, Christopher B Barrett, and Mark A Constas. 2014. "Toward a Theory of Resilience for International Development Applications." Proceedings of the National Academy of Sciences of the United States of America (PNAS) 111 (40): 14625-30. https://doi.org/10.1073/pnas.1320880111.

Béné, Christophe, Rachel Godfrey Wood, Andrew Newsham, and Mark Davies. 2012. "Resilience: New Utopia or New Tyranny? Reflection about the Potentials and Limits of the Concept of Resilience in Relation to Vulnerability Reduction Programmes." IDS Working Papers. https://doi.org/10.1111/j.2040-0209.2012.00405.x.

Berhanu, Wassie. 2011. "Recurrent Shocks, Poverty Traps and the Degradation of Pastoralists' Social Capital in Southern Ethiopia." African Journal of Agricultural and Resource Economics 6 (1): 1-15. https://ideas.repec.org/a/ags/afjare/156950.html.

Berkes, Fikret, and Helen Ross. 2013. "Community Resilience: Toward an Integrated Approach." Society \& Natural Resources 26 (1): 5-20. https://doi.org/10.1080/08941920.2012.736605.

Braun, Boris, and Tibor Assheuer. 2011. "Floods in Megacity Environments: Vulnerability and Coping Strategies of Slum Dwellers in Dhaka/Bangladesh." Natural Hazards 58 (2): 771-87. https://doi.org/10.1007/s11069-011-9752-5.

Bull-Kamanga, Liseli, Khady Diagne, Allan Lavell, Esteban Leon, Fred Lerise, Helen MacGregor, Andrew Maskrey. 2003. "From Everyday Hazards to Disasters: The Accumulation of Risk in Urban Areas." Environment and Urbanization 15 (1): 193-204. https://doi.org/10.1177/095624780301500109. 
Campbell, Karen A., Finn Laurien, Jeffrey Czajkowski, Adriana Keating, Stefan Hochrainer-Stigler, and Marilyn Montgomery. 2019. "First Insights from the Flood Resilience Measurement Tool: A Large-Scale Community Flood Resilience Analysis.” International Journal of Disaster Risk Reduction 40 (November): 101257. https://doi.org/10.1016/j.ijdrr.2019.101257.

Carpenter, Steve, Brian Walker, J. Marty Anderies, and Nick Abel. 2001. "From Metaphor to Measurement: Resilience of What to What?" Ecosystems 4: 765-81. https://doi.org/10.1007/ s10021-001-0045-9.

Carter, Michael R., Peter D. Little, Tewodaj Mogues, and Workneh Negatu. 2007. "Poverty Traps and Natural Disasters in Ethiopia and Honduras." World Development 35 (5): 835-56. https://doi.org/10.1016/j.worlddev.2006.09.010.

Central Intelligence Agency (CIA) World Factbook. 2018. "The World Factbook 2018." https://www.cia.gov/library/publications/the-world-factbook/geos/af.html.

Centre for Research on the Epidemiology of Disasters (CRED). 2015. The Human Cost of Weather Related Disasters - 1995-2015. Brussels, Belgium. https://www.unisdr.org/files/46796_cop21 weatherdisastersreport2015.pdf

. 2018. Natural Disaster 2017. Brussels: https://cred.be/sites/default/files/adsr_2017.pdf.

Constas, M., T. Frankenberger, and J. Hoddinott. 2014. "Resilience Measurement Principles: Toward an Agenda for Measurement Design. Resilience Measurement.” Technical Series No. 1. Rome: Food Security Information Network. https:/www.fsnnetwork.org/sites/default/files/ FSINRMTS1final.pdf.

Davoudi, Simin, Keith Shaw, L. Jamila Haider, Allyson E. Quinlan, Garry D. Peterson, Cathy Wilkinson, Hartmut Fünfgeld, Darryn McEvoy, Libby Porter, and Simin Davoudi. 2012. "Resilience: A Bridging Concept or a Dead End? 'Reframing' Resilience: Challenges for Planning Theory and Practice Interacting Traps: Resilience Assessment of a Pasture Management System in Northern Afghanistan Urban Resilience: What Does It Mean in Planning Practice? Resilience as a Useful Concept for Climate Change Adaptation? The Politics of Resilience for Planning: A Cautionary Note." Planning Theory \& Practice 13 (2): 299-333. https://doi.org/10.1080/ 14649357.2012.677124.

Engle, Nathan L. 2011. “Adaptive Capacity and Its Assessment.” Global Environmental Change 21 (2): 647-56. https://doi.org/10.1016/J.GLOENVCHA.2011.01.019.

Fernandez, Rogelio, and Haris Sanahuj. 2012. "Linkages between Population Dynamics, Urbanization Processes and Disaster Risks: A Regional Vision of Latin America." UNISDR AM, UNHABITAT and UNFPA. https://www.preventionweb.net/publications/view/31104.

Folke, Carl. 2006. "Resilience: The Emergence of a Perspective for Social-Ecological Systems Analyses.” Global Environmental Change 16 (3): 253-67. https://doi.org/10.1016/j.gloenvcha.2006.04.002.

Frankenberger, Timothy, Mark A. Constas, Suzanne Nelson, and Laurie. Starr. 2014. Resilience Programming among Nongovernmental Organizations: Lessons for Policymakers. Washington, DC: IFPRI Food Policy Report. http://dx.doi.org/10.2499/9780896295650. 
Frankenberger, Timothy, Monica Mueller, Tom Spangler, and Sara Alexander. 2013. Community Resilience: Conceptual Framework and Measurement Feed the Future Learning Agenda. Rockville, MD: Westat. https://agrilinks.org/library/community-resilience-conceptual-framework-andmeasurement-feed-future-learning-agenda.

Global Facility for Disaster Reduction and Recovery (GFDRR). 2017. Disaster Risk Profile Afghanistan. Washington, DC. https://www.gfdrr.org/sites/default/files/afghanistan_low_FINAL.pdf.

Gostelow, Lola, Gwenola Desplats, Jeremy Shoham, Carmel Dolan, and Peter Hailey. 2016. "Nutrition and Resilience: A Scoping Study." 1. Emergency Nutrition Network (ENN). https://www.ennonline.net/attachments/2450/Resilience-report-final.pdf.

Guha-Sapir, Debarati, and Regina Below. 2002. "The Quality and Accuracy of Disaster Data a Comparative Analysis of Thee Global Datasets." https:/www.gfdrr.org/sites/gfdrr/files/ publication/The Quality and Accuracy Disaster Data a Comparative Analysis of Three Global Data Sets.pdf.

Hallegatte, Stephane. 2011. "How Economic Growth and Rational Decisions Can Make Disaster Losses Grow Faster than Wealth." World Bank Policy Research Working Paper No.5617. https://doi.org/10.1596/1813-9450-5617.

Harwitasari, D., and Jacko A. van Ast. 2011. "Climate Change Adaptation in Practice: People's Responses to Tidal Flooding in Semarang, Indonesia." Journal of Flood Risk Management 4 (3): 216-33. https://doi.org/10.1111/j.1753-318X.2011.01104.x.

Heine, Reuben A., and Nicholas Pinter. 2012. "Levee Effects upon Flood Levels: An Empirical Assessment.” Hydrological Processes 26 (21): 3225-40. https://doi.org/10.1002/hyp.8261.

Heltberg, Rasmus, Naomi Hossain, and Anna Reva. 2012. "Living through Crises: How the Food, Fuel, and Financial Shocks Affect the Poor." World Bank Publications No. 6013. https://ideas.repec.org/b/wbk/wbpubs/6013.html.

Holling, C. S. 1973. "Resilience and Stability of Ecological Systems." Annual Review of Ecology and Systematics 4 (1): 1-23. https://doi.org/10.1146/annurev.es.04.110173.000245.

1996. "Engineering Resilience versus Ecological Resilience." In Engineering within Ecological Constraints, 31-44. Washington, DC: The National Academic Press.

- 2001. "Understanding the Complexity of Economic, Ecological, and Social Systems." Ecosystems 4 (5): 390-405.

Jakobsen, Kristian Thor. 2012. "In the Eye of the Storm-The Welfare Impacts of a Hurricane." World Development 40 (12): 2578-89. https://doi.org/10.1016/j.worlddev.2012.05.013.

Keating, Adriana, Karen Campbell, Reinhard Mechler, Piotr Magnuszewski, Junko Mochizuki, Wei Liu, Michael Szoenyi, and Colin McQuistan. 2016. "Disaster Resilience: What It Is and How It Can Engender a Meaningful Change in Development Policy." Development Policy Review 35 (1): 6591. http://pure.iiasa.ac.at/id/eprint/11897/. 
Keating, Adriana, Karen Campbell, Michael Szoenyi, Colin McQuistan, David Nash, and Meinrad Burer. 2017. "Development and Testing of a Community Flood Resilience Measurement Tool." Natural Hazards and Earth System Sciences 17 (1): 77-101. https://doi.org/DOI:10.5194/nhess17-77-2017.

Kundzewicz, Zbigniew W., Shinjiro Kanae, Sonia I. Seneviratne, John Handmer, Neville Nicholls, Pascal Peduzzi, Reinhard Mechler. 2014. "Flood Risk and Climate Change: Global and Regional Perspectives." Hydrological Sciences Journal 59 (1): 1-28. https://doi.org/10.1080/02626667.2013.857411.

Kunreuther, Howard, Robert Meyer, and Erwann Michel-Kerjan. 2013. "Overcoming Decision Biases to Reduce Losses from Natural Catastrophes.” In Behavioral Foundations of Policy, edited by Eldar Shafir, 398-413. Princeton, NJ: Princeton University Press.

Ladds, Monique, Adriana Keating, John Handmer, and Liam Magee. 2017. "How Much Do Disasters Cost? A Comparison of Disaster Cost Estimates in Australia." International Journal of Disaster Risk Reduction 21 (March): 419-29. http://pure.iiasa.ac.at/id/eprint/14291/.

Laurien, Finn, Keating Adriana, Mechler Reinhard, Etienne Emilie, Velev Stefan, Szoenyi Michael, McQuistan Colin, lanni Fransisco, and Campbell Karen. 2019. "Lessons Learned from Measuring Flood Resilience.” WP-19-005. Laxenburg, Austria.

Maxwell, Dan, Mark Constas, Timothy Frankenberger, Dorothea Klaus, and Nancy Mock. 2015. "Qualitative Data and Subjective Indicators for Resilience Measurement Resilience Measurement Technical Working Group. Technical Series No. 4." Rome. http://www.fsincop.net/fileadmin/user_upload/fsin/docs/resources/1_FSIN_TechnicalSeries_ 4.pdf.

Mechler, R., J. Czajkowski, H. Kunreuther, E. Michel-Kerjan, W. Botzen, A. Keating, C. McQuistan, N. Cooper, and I. O’Donnell. 2014. "Making Communities More Flood Resilient: The Role of Cost Benefit Analysis and Other Decision-Support Tools in Disaster Risk Reduction.” http://pure.iiasa.ac.at/id/eprint/11193/.

Mechler, R., S. Hochrainer-Stigler, D. Kull, S. Chopde, P. Singh, and S. Wajih. 2008. "Uttar Pradesh Drought Cost-Benefit Analysis. From Risk to Resilience." Working Paper 5. M. Moench, E. Caspari, and A. Pokhrel (eds.). Kathmandu, Nepal: ISET, ISET-Nepal and ProVention..

Meerow, Sara, and Joshua P. Newell. 2015. "Resilience and Complexity: A Bibliometric Review and Prospects for Industrial Ecology." Journal of Industrial Ecology 19 (2): 236-51. https://doi.org/10.1111/jiec.12252.

Mercy Corps. 2013. "Resilience, Development and Disaster Risk Reduction." https://www.mercycorps.org/research-resources/resilience-development-and-disaster-riskreduction.

Mercy Corps Indonesia. 2016. "Application of FRMT to Enhance Community-Based Flood Resilience in Semarang City, Central Java, Indonesia." Zurich Flood Resilience Project (personal consultation). Zurich. 
Mitchell, Tom, and Katie Harris. 2012. "Resilience: A Risk Management Approach.” 01/2012. ODI Background Notes. https://www.odi.org/sites/odi.org.uk/files/odi-assets/publications-opinionfiles/7552.pdf.

Mora, M. G., M. Ordaz, L. E. Yamin, and O. D. Cardona. 2009. "Relaciones Beneficio Costo Probabilistas Del Refuerzo Sísmico de Edificios." In Relaciones Beneficio Costo Probabilistas Del Refuerzo Sísmico de Edificios. Memorias Del IV Congreso Nacional de Ingeniería Sísmica, 13:14. Pereira: Colombia.

Multihazard Mitigation Council (MMC). 2005. "Natural Hazard Mitigation Saves: An Independent Study to Assess the Future Savings from Mitigation Activities, Volumes 1 and 2, Report to US Congress on Behalf of the National Institute of Building Sciences." 1. Washington, DC. http://www.floods.org/PDF/MMC_Volume1_FindingsConclusionsRecommendations.pdf.

Oddsdóttir, Freyja, Brian Lucas, and Émilie Combaz. 2013. Measuring Disaster Resilience. UK: GSDRC University of Birmingham.

Ostadtaghizadeh, Abbas, Ali Ardalan, Douglas Paton, Hossain Jabbari, and Hamid Reza Khankeh. 2015. "Community Disaster Resilience: A Systematic Review on Assessment Models and Tools." PLoS Currents 7 (DISASTERS). https://doi.org/10.1371/currents.dis. f224ef8efbdfcf1d508dd0de4d8210ed.

Pasteur, Katherine, and Colin McQuistan. 2016. "From Risk to Resilience: A Systems Approach to Building Long-Term, Adaptive Wellbeing for the Most Vulnerable.” RPBS1. Rugby, UK. http://repo.floodalliance.net/jspui/handle/44111/2722.

Rose, Adam. 2009. "Economic Resilience to Disaster." Published Articles \& Papers. Paper 75. https://create.usc.edu/sites/default/files/publications/economicresiliencetodisasters_2.pdf.

Rus, Katarina, Vojko Kilar, and David Koren. 2018. "Resilience Assessment of Complex Urban Systems to Natural Disasters: A New Literature Review." International Journal of Disaster Risk Reduction 31 (October): 311-30. https://doi.org/10.1016/J.IJDRR.2018.05.015.

Schipper, Lisa, and Lara Langston. 2015. "A Comparative Overview of Resilience Measurement Frameworks Analysing Indicators and Approaches." ODI Working Paper 422. London, UK: Overseas Development Institute. https://www.odi.org/sites/odi.org.uk/files/odiassets/publications-opinion-files/9754.pdf.

Schipper, Lisa, and Mark Pelling. 2006. "Disaster Risk, Climate Change and International Development: Scope for, and Challenges to, Integration." Disasters 30 (1): 19-38. https://doi.org/10.1111/j.1467-9523.2006.00304.x.

Semarang City. 2016. Resilient Samarang Moving Together towards a Resilient Semarang. Edited by Rockefeller Foundation and Mercy Corps Indonesia. Samarang: 100 Resilient Cities.

Sendzimir, J., P. Magnuszewski, Z. Flachner, P. Balogh, G. Molnar, A. Sarvari, and Z. Nagy. 2008. "Assessing the Resilience of a River Management Regime: Informal Learning in a Shadow Network in the Tisza River Basin." Ecology and Society 13 (1): art.11. http://pure.iiasa.ac.at/id/eprint/8478/. 
Sudmeier-Rieux, K., U. Fra.Paleo, M. Garschagen, M. Estrella, F. G. Renaud, and M. Jaboyedoff. 2015. "Opportunities, Incentives and Challenges to Risk Sensitive Land Use Planning: Lessons from Nepal, Spain and Vietnam." International Journal of Disaster Risk Reduction 14: 205-24. https://doi.org/10.1016/j.ijdrr.2014.09.009.

Tol, Richard S.J., and Gary W Yohe. 2007. "Infinite Uncertainty, Forgotten Feedbacks, and Cost-Benefit Analysis of Climate Policy." Climatic Change 83 (4): 429-42. https://doi.org/10.1007/s10584-007-9258-z.

United Nations Development Programme (UNDP). 2018. "Human Development Indices and Indicators: 2018 Statistical Update Briefing Note for Countries on the 2018 Statistical Update." http://hdr.undp.org/en/data.

United Nations Economic and Social Commission for Asia and the Pacific (UNESCAP). 2015. "Overview of Natural Disasters and Their Impacts in Asia and the Pacific, 1970-2014." https://www.unescap.org/sites/default/files/Technical paper-Overview of natural hazards and their impacts_final.pdf.

United Nations Office for Disaster Risk Reduction (UNISDR). 2005. "Hyogo Framework for Action 2005-2015: Building the Resilience of Nations and Communities to Disasters." In Extract from the Final Report of the World Conference on Disaster Reduction (A/CONF. 206/6), 380:25. Kobe. https://www.unisdr.org/we/inform/publications/1037.

2011. Global Assessment Report on Disaster Risk Reduction. Geneva. https://www.unisdr.org/we/inform/publications/19846

2013. "From Shared Risk to Shared Value: The Business Case for Disaster Risk Reduction The 2013 Global Assessment Report on Disaster Risk Reduction." International Journal of Disaster Resilience in the Built Environment 4 (3). https://doi.org/10.1108/IJDRBE-06-20130020.

_ 2015. "Sendai Framework for Disaster Risk Reduction 2015-2030." Third United Nations World Conference on Disaster Risk Reduction, 1-25 March.

—. 2018. "UNISDR Assesses Progress on Sendai Framework - UNISDR." https://www.unisdr.org/archive/58704.

Venton, Cabot Courtenay, and Paul Venton. 2004. "Disaster Preparedness Programmes in India: A Cost Benefit Analysis." https://www.odi.org/sites/odi.org.uk/files/odi-assets/publicationsopinion-files/506.pdf.

Vincent, Katharine. 2007. "Uncertainty in Adaptive Capacity and the Importance of Scale." Global Environmental Change 17 (1): 12-24. https://doi.org/10.1016/j.gloenvcha.2006.11.009.

Wamsler, Christine, and Ebba Brink. 2014. "Planning for Climatic Extremes and Variability: A Review of Swedish Municipalities' Adaptation Responses.” Sustainability (Switzerland) 6 (3): 1359-85. https://doi.org/10.3390/su6031359. 
Welsh, Marc. 2014. "Resilience and Responsibility: Governing Uncertainty in a Complex World." Geographical Journal 180 (1): 15-26. https://doi.org/10.1111/geoj.12012.

Winderl, Thomas. 2014. "Disaster Resilience Measurements: Stocktaking of Ongoing Efforts in Developing Systems for Measuring Resilience." https://www.preventionweb.net/files/37916_ disasterresiliencemeasurementsundpt.pdf.

Wirtz, Angelika, Wolfgang Kron, Petra Löw, and Markus Steuer. 2014. "The Need for Data: Natural Disasters and the Challenges of Database Management." Natural Hazards 70 (1): 135-57. https://doi.org/10.1007/s11069-012-0312-4.

World Bank. 2003. Social Risk Management: The World Bank's Approach to Social Protection in a Globalizing World. Washington, DC. https://siteresources.worldbank.org/ SOCIALPROTECTION/Publications/20847129/SRMWBApproachtoSP.pdf.

Zurich. 2018. "The Zurich Flood Resilience Program- Phase 1 from 2013-2018." https://www.preventionweb.net/publications/view/59132. 


\section{Evidence from Measuring Community Flood Resilience in Asia}

Measuring community disaster resilience helps communities and organizations understand the disaster development system driving their risk and well-being outcomes. This paper highlights the importance of measuring resilience for effectively tackling the underlying drivers of risk and for building resilience. It finds that long-term and transformative approaches and systemic interventions involving multiple stakeholders are most likely to succeed and have cobenefits for community development.

\section{About the Asian Development Bank}

ADB is committed to achieving a prosperous, inclusive, resilient, and sustainable Asia and the Pacific, while sustaining its efforts to eradicate extreme poverty. Established in 1966, it is owned by 68 members -49 from the region. Its main instruments for helping its developing member countries are policy dialogue, loans, equity investments, guarantees, grants, and technical assistance. 